\title{
Mn-Fe Layered Double Hydroxide Intercalated with Ethylene-Diaminetetraacetate Anion: Synthesis and Removal of As(III) from Aqueous Solution around pH 2-11
}

\author{
Guifeng Liu ${ }^{1}$, Zongqiang Zhu ${ }^{1,2}, \mathbb{C}^{\mathbb{D}}$, Ningning Zhao ${ }^{1}$, Yali Fang ${ }^{1}$, Yingying Gao ${ }^{1}$, \\ Yinian Zhu ${ }^{1, * \mathbb{B}}$ and Lihao Zhang ${ }^{1}$ \\ 1 Guangxi Key Laboratory of Environmental Pollution Control Theory and Technology, \\ Guilin University of Technology, Guilin 541004, China; liuguifengmail@163.com (G.L.); \\ 18835175975@163.com (N.Z.); fangyali0610@163.com (Y.F.); gyy88882020@163.com (Y.G.); \\ lhzhang@glut.edu.cn (L.Z.) \\ 2 State Key Laboratory of Environmental Aquatic Chemistry, Research Center for Eco-Environmental Sciences \\ Chinese Academy of Sciences, Beijing 100085, China \\ * Correspondence: zhuzongqiang@glut.edu.cn (Z.Z.); zhuyinian@glut.edu.cn (Y.Z.)
}

Received: 28 October 2020; Accepted: 10 December 2020; Published: 14 December 2020

check for updates

\begin{abstract}
A novel adsorbent Mn-Fe layered double hydroxides intercalated with ethylenediaminetetraacetic (EDTA@MF-LDHs) was synthesized by a low saturation coprecipitation method. The behavior and mechanism of As(III) removed by EDTA@MF-LDHs were investigated in detail in comparison with the carbonate intercalated $\mathrm{Mn}$-Fe layered double hydroxides $\left(\mathrm{CO}_{3} @ \mathrm{MF}-\mathrm{LDHs}\right)$. The results showed that EDTA@MF-LDHs had a higher removal efficiency for As(III) than As(V) with a broader $\mathrm{pH}$ range than $\mathrm{CO}_{3} @ \mathrm{MF}-\mathrm{LDH}$. The large adsorption capacity of EDTA@MF-LDHs is related to its large interlayer spacing and the high affinity of its surface hydroxyl groups. The maximum adsorption capacity for As(III) is $66.76 \mathrm{mg} / \mathrm{g}$ at $\mathrm{pH}$ 7. The FT-IR and XPS characterization indicated that the removal mechanism of the As(III) on EDTA@MF-LDHs include surface complexation, redox, and ion exchange.
\end{abstract}

Keywords: LDHs; EDTA; As; redox reaction; ion exchange

\section{Introduction}

Arsenic contamination is considered one of the most serious environmental issues. Many regions of the world are facing a certain degree of arsenic pollution [1-3]. The level of arsenic in many drinking water sources in Bangladesh and India is more than 20 times the standard limit (10 ppb) set by the World Health Organization (WHO) [4]. Arsenic pollution incidents of varying degrees have occurred in Guangxi, Henan, Gansu, Xinjiang, and Shandong provinces in China. Nearly 20 million people have been exposed to arsenic pollution, and nearly 580,000 square kilometers have been polluted by arsenic in the country [5]. Chile, Mexico, Argentina, Poland, Canada, Hungary, Japan, and other countries have also reported incidents of excessive arsenic concentration. About 200 million people are being exposed to excessive arsenic through consumption of contaminated drinking water according to the statistics from all over the world [6]. Studies have demonstrated that arsenic contaminated waterbodies have a significant potential to cause liver, lung, kidney, bladder, and skin cancer [7], and affect the intellectual development of children [8,9]. Among various technologies to solve the problem of arsenic contamination, adsorption, which is believed to be a simple, high efficiency, and low cost process, is the main method for the removal of arsenic. Most studies focus on the treatment of arsenic-containing 
wastewater under acidic conditions. However, in some cases, the arsenic-containing wastewater is strong alkaline such as the leachate wastewater discharged from the antimony refining process. For example, the $\mathrm{pH}$ of the raw water discharged from a smelter in Guangxi can be as high as 12.5. Nevertheless, there are only a few reports on the directly effective treatment of arsenic-containing wastewater under alkaline conditions. Due to the presence in an electrically neutral nonionic form $\left(\mathrm{H}_{3} \mathrm{AsO}_{3}\right)$ in natural water [10], As(III) is generally reported to have low affinity to the surface of some adsorbents compared with $\mathrm{As}(\mathrm{V})$ [11-13]. Furthermore, valence has a great influence on the behavior and toxicity of arsenic [14,15]. Compared with As(V), As(III) has higher toxicity, solubility, and mobility, which can be absorbed faster in a biological system [16,17]. So it is desirable to develop an effective adsorbent for As(III) removal.

Recently, layered double hydroxides (LDHs) have been extensively studied owing to their advantage of large surface area, high anion adsorption/exchange capacity, structure controllability, and "memory effect" (The calcined product of LDHs, which is generally a mixed metal oxide, is exposed to water and anions under certain conditions, the structure of the layered LDHs can be restored) [18]. NMMB (Precipitation of Ni/Mn-LDHs onto pristine biochars) was prepared for As(V) removal [19], layered double hydroxide intercalated with $\mathrm{MoS}_{4}{ }^{2-}$ for oxoanions of As(III), As(V), and $\mathrm{Cr}(\mathrm{VI})$ uptake [20]; Mg-Al-Cl layered double hydroxide for simultaneous removal of $\mathrm{Cu}$ (II) and $\mathrm{Cr}$ (VI) [21]; edta.Mg-Al LDH for the uptake of $\mathrm{Cu}^{2+}$ and $\mathrm{Cd}^{2+}$ from an aqueous solution [22]. Currently, LDHs have been applied in practice; for example, the calcined Mn-Fe LDH was used for treatment of arsenic effluent and the study proved that calcined Mn-Fe LDH was an efficient adsorbent for arsenic effluent for $2 \mathrm{~h}$ [23]; the nanocrystallined $\mathrm{Mg} / \mathrm{Al} \mathrm{LDHs}$ was used for treatment of natural groundwater that contained arsenic and natural organic matter (NOM) [24]; the core-shell bio-ceramic/Zn-layered was used for phosphorus-containing municipal wastewater treatment [25]; and in the study of Jiang et al., high As(III) concentration in Bangladesh groundwater can be reduced to meet the national drinking water standards $(<50 \mu \mathrm{g} / \mathrm{L})$ for $2 \mathrm{~g} / \mathrm{L}$ of $\mathrm{Mg}-\mathrm{Fe}-\mathrm{Cl} \mathrm{LDH}$ [26].

The representative material of LDHs is $\mathrm{Mg}-\mathrm{Al}$ hydrotalcite $\left(\left[\mathrm{Mg}_{6} \mathrm{Al}_{2}(\mathrm{OH})_{16}\right]\left(\mathrm{CO}_{3}\right)_{3} \cdot 4 \mathrm{H}_{2} \mathrm{O}\right)$, which is a natural occurring mineral. The basic layer structure of LDHs is based on that of brucite $\left[\mathrm{Mg}(\mathrm{OH})_{2}\right]$, in which $\mathrm{Mg}^{2+}$ is partially replaced by $\mathrm{Al}^{3+}$, and the positive charge is compensated by negative ions located in the interlayer space [27,28]. Taylor (1969) and Allmann (1968) first confirmed the structure and characteristics of LDHs by X-ray diffraction analysis [29,30]. The reported LDHs materials, which main laminates are composed of divalent and trivalent metal elements, mainly use $\mathrm{Mg}-\mathrm{Al}, \mathrm{Ni}-\mathrm{Al}$, $\mathrm{Mn}-\mathrm{Al}$, and Mg-Fe as metal laminates. Organic-modified LDHs have also been investigated [31-33]. It was confirmed that $\mathrm{Mn}$ and Fe enriched materials could oxidize As(III) to As(V) and reacted better in As(III) uptake than that of As(V) [34,35]. However, using iron and manganese simultaneously as the laminates are rarely reported, and EDTA intercalation Mn-Fe LDHs have never been reported. As a non-toxic, powerful chelating agent with abundant function groups, EDTA is widely used for heavy metals removal [36]. Many studies have shown that EDTA intercalation into LDHs can improve the adsorption efficiency [37,38] as well as retain their chelating ability [39].

The main objectives of this study were: (1) synthesis of the intercalated Mn-Fe layered double hydroxides (intercalated MF-LDHs) and characterization them with a variety of techniques; (2) systematically examination the effect of initial $\mathrm{pH}$ and adsorbent dosage on As(III) and As(V) adsorption onto EDTA@MF-LDHs; (3) analysis and discussing the mechanism of As(III) adsorption on EDTA@MF-LDHs.

\section{Materials and Methods}

\subsection{Materials}

All the reagents were in analytical purity and used without further purification. As(III) stock solutions and $\mathrm{As}(\mathrm{V})$ stock solutions were prepared using $\mathrm{NaAsO}_{2}$ and $\mathrm{NaAsO}_{4} \cdot 12 \mathrm{H}_{2} \mathrm{O}$, respectively. 
Arsenic working solutions were freshly prepared by diluting arsenic solutions with $\mathrm{NaCl}$ solutions which made the background ionic strength of arsenic solution to be $0.01 \mathrm{~mol} / \mathrm{L}$.

\subsection{Preparation of Intercalated $\mathrm{Mn}-\mathrm{Fe} \mathrm{LDHs}$}

Intercalated Mn-Fe LDHs were synthesized by the co-precipitation of Mn and Fe salts at constant $\mathrm{pH}$ with low supersaturation. Detailed descriptions of synthesis methods are given as follows.

\subsubsection{Preparation of EDTA@MF-LDHs}

In order to prevent the interference of carbonate, EDTA@MF-LDHs was prepared under a nitrogen atmosphere: (1) $\mathrm{FeCl}_{3} \cdot 6 \mathrm{H}_{2} \mathrm{O}(4.505 \mathrm{~g})$ and $\mathrm{MnCl}_{2} \cdot 4 \mathrm{H}_{2} \mathrm{O}(6.583 \mathrm{~g}$ ) were dissolved in $50 \mathrm{~mL}$ deoxygenated water to get the mixed metal salt solution (Sol S1); (2) NaOH (9.6 g) and EDTA.2Na (4.653 g) were dissolved in $100 \mathrm{~mL}$ deoxygenated water to get the base solution (Sol B1); (3) Sol B1 was added into a beaker containing $100 \mathrm{~mL}$ deoxygenated water until the solution $\mathrm{pH}$ value reached $12 \pm 0.1$, then Sol $\mathrm{S} 1$ and Sol B1 were added dropwise at the rate of keeping the reaction $\mathrm{pH}$ constant at $12 \pm 0.1$ under a nitrogen atmosphere with continuous magnetic stirring. After dropping, the mixture was stirred continuously for $10 \mathrm{~min}$; (4) Then the reaction system was transferred to a water bath pot and aged for $2 \mathrm{~h}$ at $60^{\circ} \mathrm{C}$; (5) Finally, the product was washed 3 times by ultra-pure water using vacuum filter before it was dried at $-40^{\circ} \mathrm{C}$ in vacuum freeze dryer overnight.

\subsubsection{Preparation of $\mathrm{CO}_{3} @ \mathrm{MF}-\mathrm{LDHs}$}

$\mathrm{CO}_{3} @ M F-L D H s$ has been used as reference material to demonstrate the effect of the interlayer anion. The same quantities of $\mathrm{FeCl}_{3} \cdot 6 \mathrm{H}_{2} \mathrm{O}$ and $\mathrm{MnCl}_{2} \cdot 4 \mathrm{H}_{2} \mathrm{O}$ as above were dissolved in $50 \mathrm{~mL}$ ultra-pure water to get mixed metal salt solution ( $\mathrm{Sol} \mathrm{S} 2$ ). The mixed base solution Sol B2 was prepared from $\mathrm{NaOH}(6.4 \mathrm{~g})$ and $\mathrm{Na}_{2} \mathrm{CO}_{3}(7.066 \mathrm{~g})$ dissolved in $100 \mathrm{~mL}$ ultra-pure water. Sol $\mathrm{B} 2$ was dropped into a beaker containing $100 \mathrm{~mL}$ ultra-pure water until the solution $\mathrm{pH}$ value reached $12 \pm 0.1$, then Sol S2 and Sol B2 were added dropwise at the rate of keeping the reaction $\mathrm{pH}$ constant at $12 \pm 0.1$. The whole process was performed under magnetic stirring continuously for $10 \mathrm{~min}$ after the dripping process was finished. The next steps were the same as for the preparation of EDTA@MF-LDHs.

\subsection{Characterization}

Phases of the intercalated Mn-Fe LDHs composites before and after arsenic removal were identified by recording their powder X-ray diffraction patterns (XRD) under $\mathrm{Cu} \mathrm{K} \alpha$ radiation with an X'Pert PRO diffractometer (PANalytical B.V., Almelo, The Netherlands). FT-IR spectra (Thermo Fisher Scientific lnc., Waltham, MA, USA) were recorded using a Bruker VERTEX 70 spectrometer by the KBr pellet method. The surface morphologies were examined by using a JEOL JSM-7900F field emission scanning electron microscopy (SEM) (Hitachi Ltd., Tokyo, Japan). The point of zero charge was determined by using a Zetasizer Nano JS90 (Malvern, UK.) by disperse $0.01 \mathrm{~g}$ material in $50 \mathrm{~mL} \mathrm{NaCl}$ solution with a concentration of $0.01 \mathrm{~mol} / \mathrm{L}$, and then ultrasonic dispersion for $30 \mathrm{~min}$. A Thermo Scientific ESCALAB 250Xi instrument (Thermo Fisher Scientific lnc., Waltham, MA, USA) was applied to collect the X-ray photoelectron spectra (XPS) and the results were analyzed using XPS peak fitting program (XPS Peak41) to obtain more detailed information about the adsorption mechanism.

\subsection{Batch Experiment}

Most elimination experiments were performed in $100 \mathrm{~mL}$ plastic centrifuge tube containing $20 \mathrm{~mL}$ As solution with initial concentrations 10 and $50 \mathrm{mg} / \mathrm{L}$, and configured with $\mathrm{NaCl}(0.01 \mathrm{~mol} / \mathrm{L})$ as background solution. Then the required sorbent was dosed. These tubes were shaken at $180 \mathrm{rpm}$ and kept the temperature at $25 \pm 1{ }^{\circ} \mathrm{C}$. Effect of solution initial $\mathrm{pH}(2-12)$ and adsorbent dose $(0.1-1.5 \mathrm{~g} / \mathrm{L})$ were tested for optimizing the initial $\mathrm{pH}$ value and dose. Sorption kinetics were examined at varied sorption time (0-1440 $\mathrm{min})$, sorption isotherm was obtained at initial As concentrations from 5 to 
$50 \mathrm{mg} / \mathrm{L}$. All the samples were filtered by $0.22 \mu \mathrm{m}$ micropore membrane and the residual As(III) and $\mathrm{As}(\mathrm{V})$ concentrations were analyzed using an inductively coupled plasma-optical emission spectrometer (ICP-OES, Optima 7000DV, Perkin-Elmer Ltd., Waltham, MA, USA).

The removal efficiency and the amount of As(III) or As(V) adsorbed on MF-LDHs were calculated by using Equations (1) and (2):

$$
\text { Efficiency }(\%)=\left(C_{o}-C_{e}\right) / C_{o} \times 100
$$

where $C_{o}$ and $C_{e}$ are the initial $\mathrm{As}(\mathrm{III})$ or $\mathrm{As}(\mathrm{V})$ concentration $(\mathrm{mg} / \mathrm{L})$ and the residual $\mathrm{As}(\mathrm{III})$ or $\mathrm{As}(\mathrm{V})$ concentration $(\mathrm{mg} / \mathrm{L})$, respectively.

$$
q_{t}=\left(C_{o}-C_{t}\right) V / W
$$

where $C_{t}, V$, and $M$ are the $\mathrm{As}(\mathrm{III})$ or $\mathrm{As}(\mathrm{V})$ concentration $(\mathrm{mg} / \mathrm{L})$ at $t$, the solution volume $(\mathrm{mL})$ and the Fe-Mn LDHs dosage (g), respectively.

\section{Results}

\subsection{Characterization of Intercalated $M n-F e-L D H s$}

\subsubsection{XRD}

The crystal structure of $\mathrm{CO}_{3} @ M F-L D H s$ and EDTA@MF-LDHs is shown in Figure 1. The XRD peaks were identified as the hydrotalcite-like phases according to the standard diffraction patterns [40-42]. The good multiple relationship between the typical planes of (003), (006), and (012) revealed a layered structure [43]. Similar to $\mathrm{CO}_{3} @ \mathrm{MF}-\mathrm{LDH}$, there is a diffraction peak of the (012) crystal plane indicating that the EDTA was inserted [44,45].

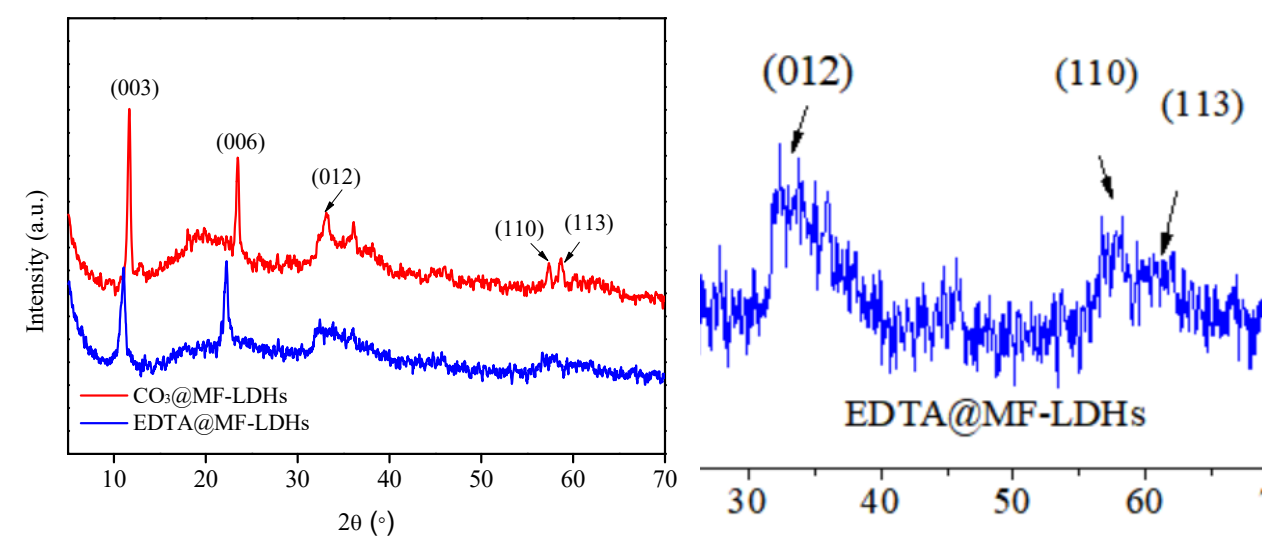

Figure 1. XRD pattern of $\mathrm{CO}_{3} @ M F-L D H s$ and EDTA@MF-LDHs.

The main XRD indexes of $\mathrm{CO}_{3} @ M F-L D H s$ and EDTA@MF-LDHs given in Table 1 showed that the interlayer spacing of $\mathrm{CO}_{3} @ M F-L D H s$ was $0.762 \mathrm{~nm}$, indicating that the interlayer anion was carbonate [42,46]. The interlayer spacing of EDTA@MF-LDHs was $0.804 \mathrm{~nm}$, which was close to the interlayer spacing of EDTA Mg-Al LDH $(0.8 \mathrm{~nm})$ synthesized by Kameda et al. [22]. However, the spacing was smaller than that reported in the related literature (1.2-1.5 nm) [34]. It may be that the [EDTA $]^{4-}$ was arranged in a single-layer inclined orientation between the layers. The crystallographic parameters a representing the distance between metal atoms in the adjacent hexagonal cell, and c representing the cell thickness, reflects the charge density of the laminate and are related to the size of interlayer anions. These values are approximately equal to $2 \mathrm{~d}(110)$ and $3 \mathrm{~d}(110)$, respectively [47]. The results show that there was a slight difference in value $a$ between the carbonate type LDHs and the ethylenediamine tetraacetate type LDHs, indicating that there were some 
differences in the laminate structure and arrangement between them, which was consistent with the XRD results.

Table 1. XRD index of $\mathrm{CO}_{3} @ M F-L D H s$ and EDTA@MF-LDHs (nm).

\begin{tabular}{ccccccc}
\hline Diffraction Index & $\mathbf{d}(\mathbf{0 0 3})$ & $\mathbf{d}(\mathbf{0 0 6})$ & $\mathbf{d}(\mathbf{0 1 2})$ & $\mathbf{d}(\mathbf{1 1 0})$ & $a=\mathbf{2 d}(\mathbf{1 1 0 )}$ & $c=\mathbf{3 d} \mathbf{( 0 0 3 )}$ \\
\hline $\mathrm{CO}_{3} @ M F-L D H s$ & 0.762 & 0.381 & 0.271 & 0.161 & 0.322 & 2.286 \\
EDTA@MF-LDHs & 0.804 & 0.400 & 0.276 & 0.162 & 0.324 & 2.412 \\
\hline
\end{tabular}

\subsubsection{SEM and EDS}

The surface morphologies of $\mathrm{CO}_{3} @ M F-L D H s$ and EDTA@MF-LDHs are illustrated in Figure 2. It can be seen that the surface of the samples was rough and porous, which was conducive to adsorption. As indicated in Figure $2 \mathrm{~A}_{1}$, the $\mathrm{CO}_{3} @ \mathrm{MF}-\mathrm{LDH}$ product had a typical flat hexagonal laminate morphology and obvious laminate accumulation phenomenon, which was a typical carbonate-type LDHs morphology with a particle size of $50 \mathrm{~nm}-200 \mathrm{~nm}$ Figure 2A 2 . The EDTA@MF-LDHs wafers with bending morphology of the laminates were prepared in the solution containing EDTA, exhibiting a rose-like agglomeration morphology on the surface of the particles with a particle size of $200 \mathrm{~nm}-500 \mathrm{~nm}$ (Figure $2 \mathrm{~B}_{1}, \mathrm{~B}_{2}$ ). This result indicated that the addition of EDTA greatly inhibited the crystal growth and induced the deformation of the laminates.

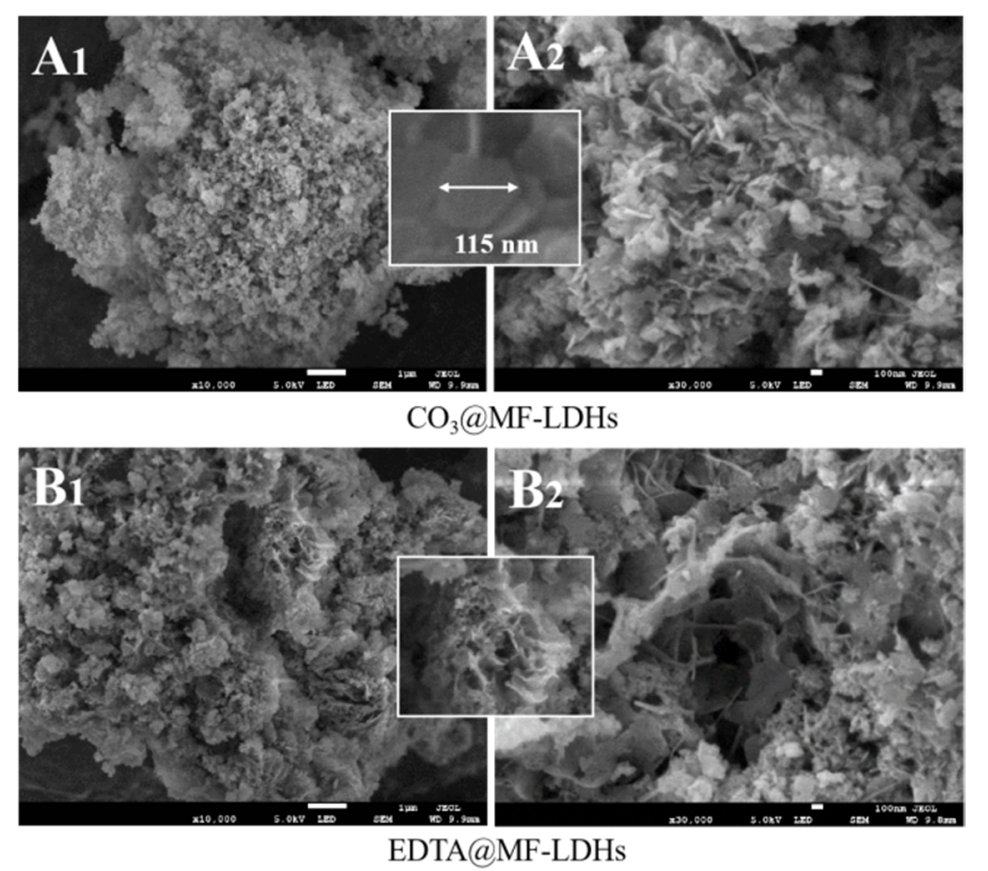

Figure 2. SEM analysis of $\mathrm{CO}_{3} @ M F-L D H s$ and EDTA@MF-LDHs. (Magnified both in 10,000 times $\left(\mathbf{A}_{\mathbf{1}}, \mathbf{B}_{\mathbf{1}}\right)$ and 30, 000 times $\left(\mathbf{A}_{\mathbf{2}}, \mathbf{B}_{\mathbf{2}}\right)$, respectively).

The energy dispersive X-ray spectroscopy (EDS) result (Supplementary Table S1) indicated that C, $\mathrm{O}, \mathrm{Fe}$, and Mn were detected on the surface of both $\mathrm{CO}_{3} @ M F-L D H s$ and EDTA@MF-LDHs with the $\mathrm{Mn} / \mathrm{Fe}$ molar ratio of 2.04 and 1.94, respectively, closing to the theoretical value of 2.0. Compared with $\mathrm{CO}_{3} @ \mathrm{MF}-\mathrm{LDHs}$, the $\mathrm{Cl}$ element was also detected on the surface of EDTA@MF-LDHs. The existence of the $\mathrm{Cl}$ element (may from $\mathrm{MnCl}_{2}$ and $\mathrm{FeCl}_{3}$ ) suggested the co-intercalation of $\mathrm{Cl}^{-}$and [EDTA] ${ }^{4-}$ in the layers [48]. 


\subsubsection{FT-IR}

The infrared spectra of the two intercalated Mn-Fe LDHs are shown in Figure 3. Both of them had strong and wide absorption bands near $3420 \mathrm{~cm}^{-1}$, which were mainly caused by the superposition of $-\mathrm{OH}$ and laminate $-\mathrm{OH}$ of interlayer water molecules, indicating that there were water molecules in the interlayer. The presence of high affinity surface hydroxyl groups indicated that they could possess a good removal capacity for As(III) in water by adsorption [9,49]. For $\mathrm{CO}_{3} @ \mathrm{MF}-\mathrm{LDHs}$ (Figure 3, the peak at $1636 \mathrm{~cm}^{-1}$ was the bending vibration of interlayer water molecules, and the peak at $1384 \mathrm{~cm}$ was the interlayer $\left[\mathrm{CO}_{3}\right]^{2-}-v_{3}$ vibration mode [42,46]. The obvious shoulder peak at $1492 \mathrm{~cm}^{-1}$ indicated highly symmetrical and well-arranged $\left[\mathrm{CO}_{3}\right]^{2-}[50]$. This result confirmed the existence of carbonate between layers. The spectrum of EDTA@MF-LDHs also showed an absorption band around $1600 \mathrm{~cm}^{-1}$ (at $1625 \mathrm{~cm}^{-1}$ ), but its intensity changed in comparison with the former, which might be the superposition peak of the interlayer water molecule and the $\mathrm{C}=\mathrm{O}$ functional group in the carboxyl group. The weak peaks at $1411 \mathrm{~cm}^{-1}$ and $1113 \mathrm{~cm}^{-1}$ corresponded to the asymmetric peak of COO- and the characteristic absorption peak of -C-N group [37], indicating the existence of [EDTA] ${ }^{4-}$. The acromion of the two samples in the low-frequency region $\left(500-800 \mathrm{~cm}^{-1}\right)$ were assigned to $\mathrm{M}-\mathrm{O}$ vibrations and $\mathrm{M}-\mathrm{O}-\mathrm{H}$ bending vibration $(\mathrm{M}=\mathrm{Mn}, \mathrm{Fe})$ [51-53], suggesting the presence of layered metal hydroxide (Figure 3). The results showed that the Mn-Fe LDHs with different morphology were successfully synthesized by changing the interlayer anion.

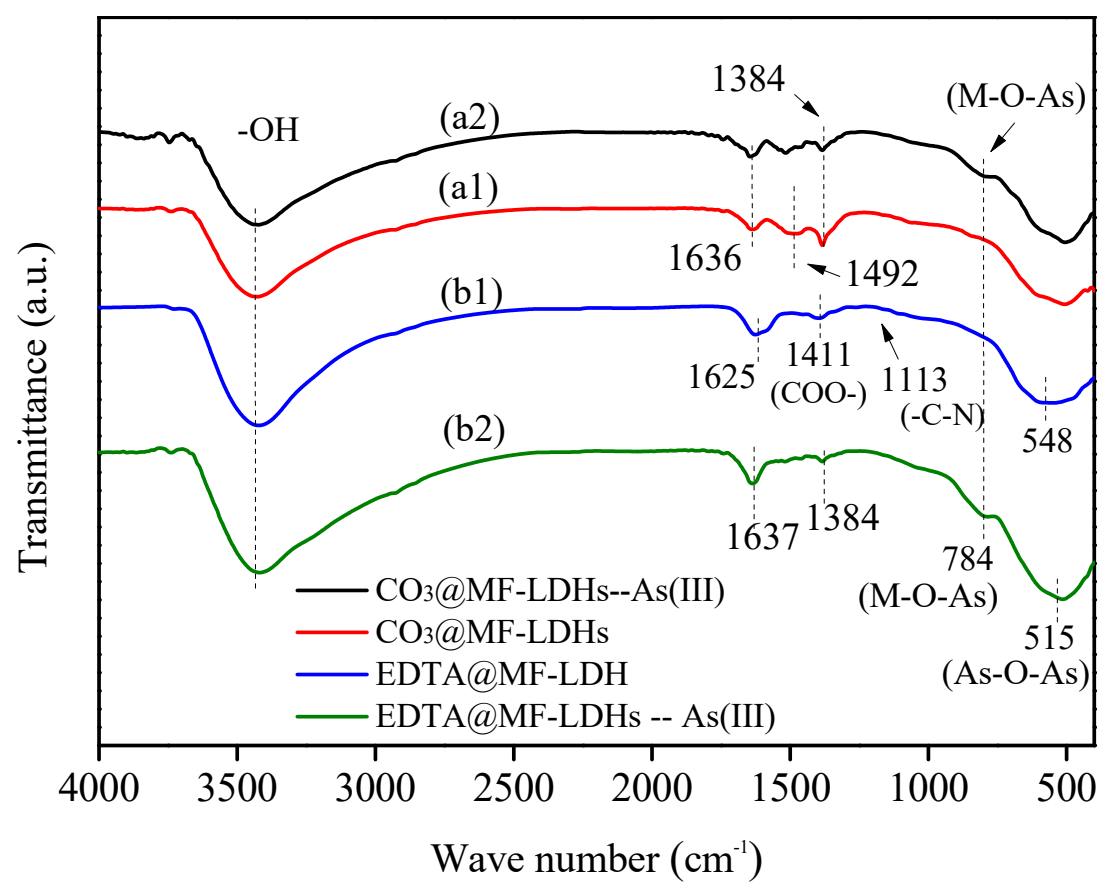

Figure 3. FT-IR pattern of $\mathrm{CO}_{3} @ \mathrm{MF}-\mathrm{LDH}$ and EDTA@MF-LDHs before and after As(III) adsorption (a1, a2, b1, b2).

\subsubsection{Point of Zero Charge}

The zeta potential versus pH for $\mathrm{CO}_{3} @$ MF-LDHs and EDTA@MF-LDHs are shown in Figure 4. With the increase of $\mathrm{pH}$ from 1.7 to 11.9 , the zeta potential of both materials decreased from around $20 \mathrm{mV}$ to around $-35 \mathrm{mV}$, that is, the surface charge of the material changed from positive to negative. The zero potential $\left(\mathrm{pH}_{\mathrm{pzc}}\right)$ values of the two materials were 4.36 and 4.55 , respectively. They were negatively charged at circumneutral $\mathrm{pH}$, indicating the existence of the surface hydroxyl groups. 


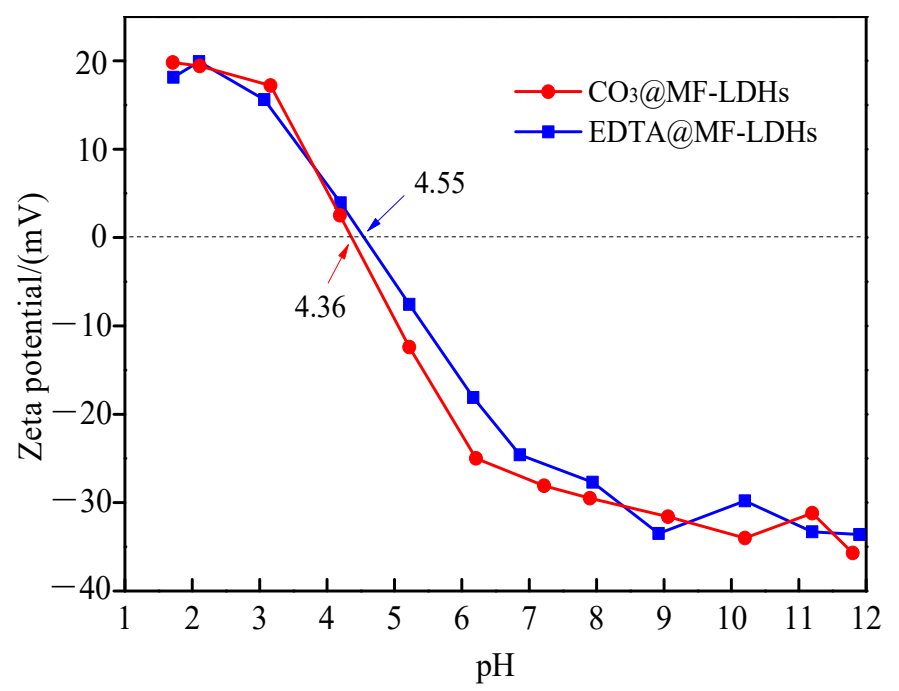

Figure 4. Zeta potentials of $\mathrm{CO}_{3} @ M F-L D H s$ and EDTA@MF-LDH.

\subsection{Sorption Performance}

\subsubsection{Effect of $\mathrm{pH}$}

Initial solution $\mathrm{pH}$ is an important parameter in the adsorption process, which affects not only the existing forms of ions in the solution, but also the charged properties of the adsorbent surface. The residual concentrations of $\mathrm{As}(\mathrm{III})$ and $\mathrm{As}(\mathrm{V})$ stock solution without sorbents did not decrease significantly (Supplementary Figure S1), i.e., no obvious hydrolytic precipitation could be observed at $\mathrm{pH} \leq 12$. Thus, the $\mathrm{As}(\mathrm{III})$ and $\mathrm{As}(\mathrm{V})$ sorption experiment was done in the $\mathrm{pH}$ range of 2.0-12.0. The effects of initial $\mathrm{pH}$ on $\mathrm{As}(\mathrm{III})$ and $\mathrm{As}(\mathrm{V})$ removal by $\mathrm{CO}_{3} @ \mathrm{MF}-\mathrm{LDHs}$ and EDTA@MF-LDHs are shown in Figure 5. For $50 \mathrm{mg} / \mathrm{L} \mathrm{As}(\mathrm{III})$, the As(III) removal by $\mathrm{CO}_{3} @ \mathrm{MF}-\mathrm{LDHs}$ was approximately constant in the $\mathrm{pH}$ range of 3.0-9.0 and decreased at $\mathrm{pH}>9$. The minimum adsorption capacity was observed at pH 12. The As(III) removal by EDTA@MF-LDHs was basically undisturbed when solution initial $\mathrm{pH}$ varied from 2 to 10; but at $\mathrm{pH}>10$, the adsorption capacity decreased sharply. At $\mathrm{pH}<9$, As(III) existed in non-ionic form of $\mathrm{H}_{3} \mathrm{AsO}_{3}{ }^{0}$. There was no electrostatic interaction between the surface of the material and the adsorbate. At $\mathrm{pH}>9$, As(III) existed mainly in the form of $\left[\mathrm{AsO}_{3}\right]^{3-}$ (Supplementary Figure S2), the negatively charged adsorbents (Figure 4) restricted the approach of As(III) due to the repulsive force [54,55]. Thus, the removal of As(III) in the $\mathrm{pH}$ range of 2 to 10 was mainly attributed to the cooperation between the functional groups on the surface of the adsorbent and the surface complexing of As(III) [56,57].

The adsorption capacities for $50 \mathrm{mg} / \mathrm{L} \mathrm{As}(\mathrm{V})$ on $\mathrm{CO}_{3} @ M F-L D H s$ and EDTA@MF-LDHs were significantly different in different $\mathrm{pH}$ ranges. The $\mathrm{CO}_{3} @ \mathrm{MF}-\mathrm{LDH}$ showed a strong $\mathrm{pH}$ dependence, consistent with the results reported recently [58,59]. With the $\mathrm{pH}$ increase from 2 to 12 , the adsorption capacity of $\mathrm{As}(\mathrm{V})$ on $\mathrm{CO}_{3} @ \mathrm{MF}-\mathrm{LDHs}$ decreased continuously from $42.66 \mathrm{mg} / \mathrm{g}$ to $1.19 \mathrm{mg} / \mathrm{g}$. The influence of the $\mathrm{pH}$ value was related to two factors, i.e., the charge on the surface of the adsorbent and the existing form of $\mathrm{As}(\mathrm{V})$ in solutions of different acidities. The dissociation of arsenate acid in solution is as follows [1]:

Step one: $\mathrm{H}_{3} \mathrm{AsO}_{4} \rightarrow \mathrm{H}_{2} \mathrm{AsO}_{4}^{-}+\mathrm{H}^{+}, \mathrm{pK}_{\mathrm{a} 1}=2.1$;

Step two: $\mathrm{H}_{2} \mathrm{AsO}_{4}{ }^{-} \rightarrow \mathrm{HASO}_{2} 2^{-}+\mathrm{H}^{+}, \mathrm{pK}$ a2 $=6.7$

Step three: $\mathrm{HAsO}_{4}{ }^{2-} \rightarrow \mathrm{AsO}_{4}{ }^{3-}+\mathrm{H}^{+}, \mathrm{pK}_{\mathrm{a} 3}=11.2$;

The $\mathrm{As}(\mathrm{V})$ in the solution mainly existed in the form of $\mathrm{H}_{2} \mathrm{AsO}_{4}{ }^{-}$, $\left[\mathrm{HAsO}_{4}\right]^{2-}$, and $\left[\mathrm{AsO}_{4}\right]^{3-}[10,19]$. With the $\mathrm{pH}$ increase from 2 to 12 , the negative charge on the surface of the adsorbent increased, leading 
to a continuous decrease in the $\mathrm{As}(\mathrm{V})$ adsorption capacity due to repulsive force. However, the $\mathrm{As}(\mathrm{V})$ removal efficiency of EDTA@MF-LDHs only had a slight change due to the hydrophobic surface of LDHs intercalated by EDTA and the protective layer on the surface of the material, which could neutralize the influence of the solution $\mathrm{pH}$ change. The adsorption capacities decreased only at $\mathrm{pH}=12$ and initial concentration of $10 \mathrm{mg} / \mathrm{L} \mathrm{As}(\mathrm{III})$ and $\mathrm{As}(\mathrm{V})$ because there were enough binding sites on the sorbents due to the relatively low concentrations of the solutions. Thus, the subsequent experiments were carried out at $\mathrm{pH}=7$.
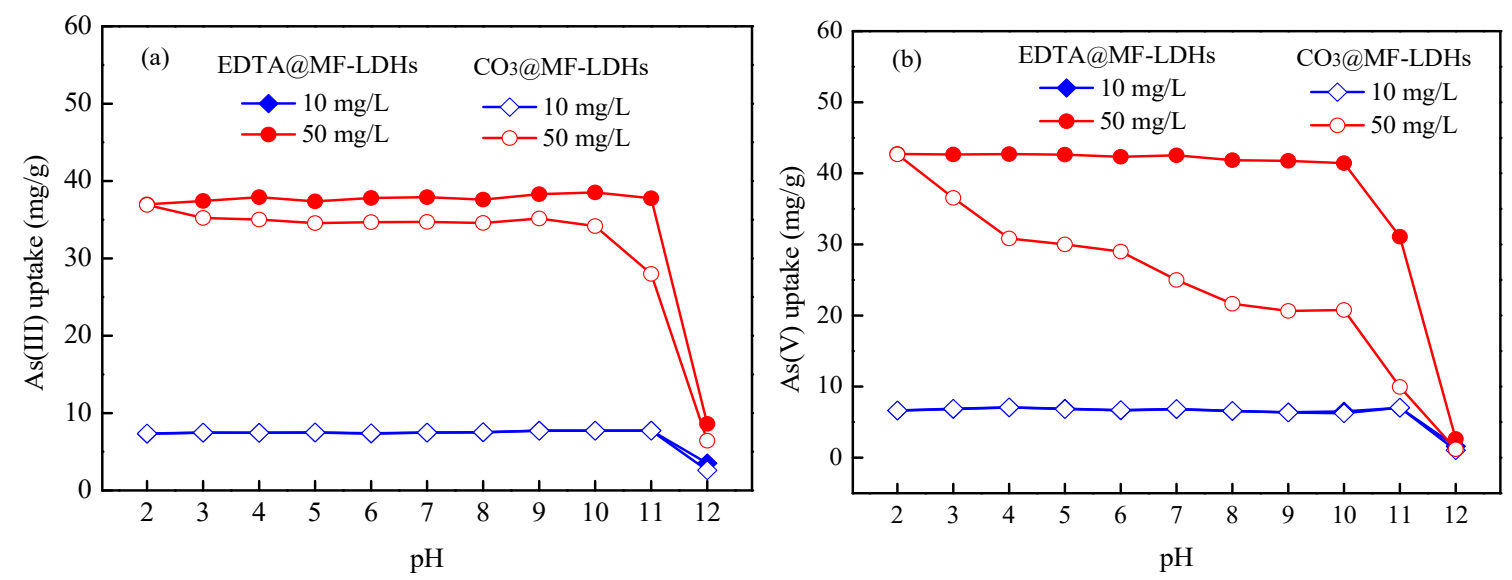

Figure 5. Effect of initial $\mathrm{pH}$ on $\mathrm{As}(\mathrm{III})$ and $\mathrm{As}(\mathrm{V})$ removal by $\mathrm{CO}_{3} @ \mathrm{MF}-\mathrm{LDHs}$ and EDTA@MF-LDHs. (Initial concentration 10 and $50 \mathrm{mg} / \mathrm{L}$; dose $1.2 \mathrm{~g} / \mathrm{L}$; and temperature $25 \pm 1^{\circ} \mathrm{C}$ ). (a) As(III) uptake on $\mathrm{CO}_{3} @$ MF-LDHs and EDTA@MF-LDHs. (b) As(V) uptake on $\mathrm{CO}_{3} @$ MF-LDHs and EDTA@MF-LDHs.

\subsubsection{Effect of Dose}

The effect of adsorbent dosage on arsenic removal from solution are shown in Figure 6a-d. For the As(III) and As(V) solution both in $10 \mathrm{mg} / \mathrm{L}$, the unit As(III) uptake decreased from $50.10 \mathrm{mg} / \mathrm{g}$ to $6.54 \mathrm{mg} / \mathrm{g}$ and unit As(V) uptake decreased from $48.41 \mathrm{mg} / \mathrm{g}$ to $7.61 \mathrm{mg} / \mathrm{g}$ with increasing the EDTA@MF-LDHs dose from $0.1 \mathrm{~g} / \mathrm{L}$ to $1.5 \mathrm{~g} / \mathrm{L}$. Correspondingly, the elimination efficiency of As(III) increased from $50.64 \%$ to $97.78 \%$ and of As(V) from $42.39 \%$ to $99.99 \%$, continuously. For the As(III) and As(V) solution both in $50 \mathrm{mg} / \mathrm{L}$, the unit uptake decreased from $93.00 \mathrm{mg} / \mathrm{g}$ to $32.33 \mathrm{mg} / \mathrm{g}$ (As(III)) and from $50.50 \mathrm{mg} / \mathrm{g}$ to $35.20 \mathrm{mg} / \mathrm{g}(\mathrm{As}(\mathrm{V}))$, respectively, while the elimination efficiency increased from $18.73 \%$ to $97.67 \%$ (As(III)) and from $9.53 \%$ to $99.58 \%$ (As(V)), respectively. Similarly, with the increase of the $\mathrm{CO}_{3} @ \mathrm{MF}-\mathrm{LDH}$ dose, the unit $\mathrm{As}(\mathrm{III})$ and $\mathrm{As}(\mathrm{V})$ uptake decreased while the elimination efficiency increased. The increase of the removal percentage with EDTA@MF-LDHs dose was attributed to surface area increase of EDTA@MF-LDHs and availability sites. The dose of $0.5 \mathrm{~g} / \mathrm{L}$ was applied in the subsequent experiments.
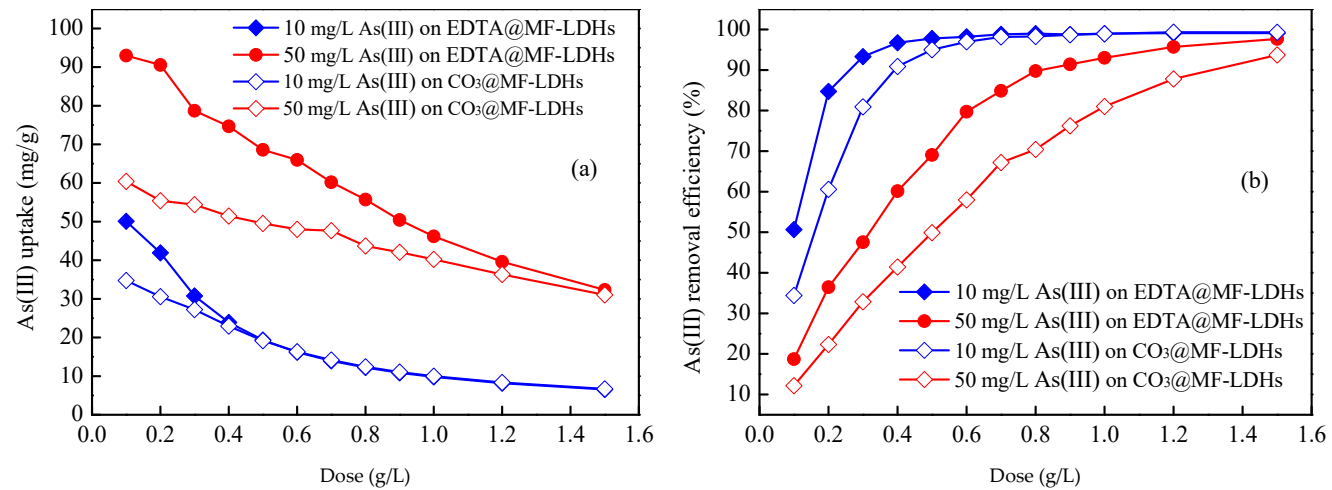

Figure 6. Cont. 

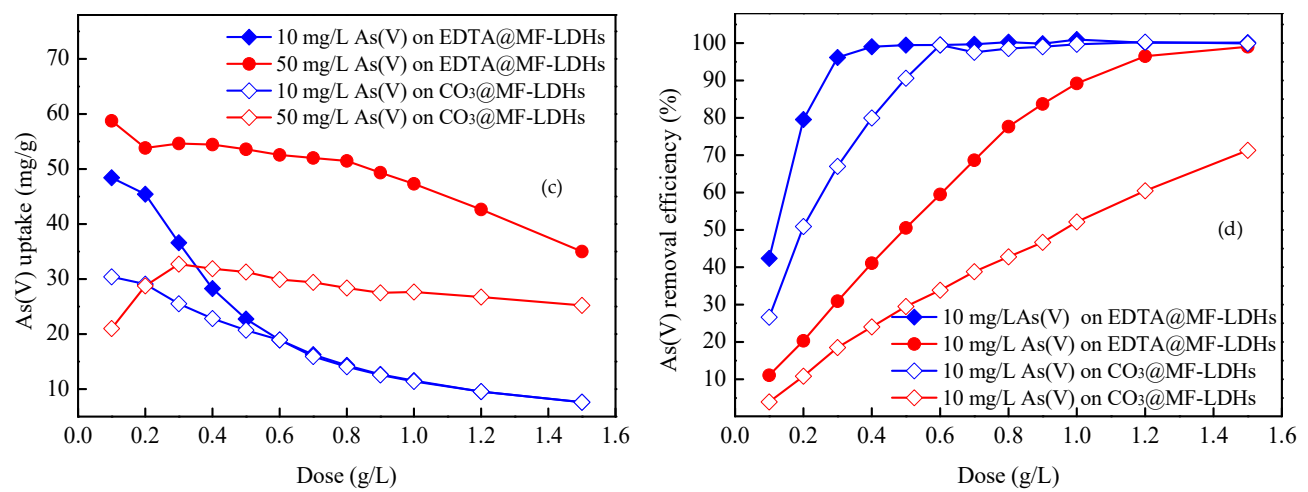

Figure 6. Effect of adsorber dose on $\mathrm{As}(\mathrm{III})$ and $\mathrm{As}(\mathrm{V})$ removal by $\mathrm{CO}_{3} @ \mathrm{MF}-\mathrm{LDH}$ and EDTA@MF-LDHs. $\left(\mathrm{CO}_{3} @\right.$ MF-LDHs, EDTA@MF-LDHs dose from 0.1 to $1.5 \mathrm{~g} / \mathrm{L}$; As initial concentration are 10 and $50 \mathrm{mg} / \mathrm{L}$; initial pH $7.0 \pm 0.2$; temperature $25 \pm 1{ }^{\circ} \mathrm{C}$ ). (a) As(III) uptake on $\mathrm{CO}_{3} @ \mathrm{MF}-\mathrm{LDH}$ and EDTA@MF-LDHs. (b) As(III) removal efficiency on $\mathrm{CO}_{3} @$ MF-LDHs and EDTA@MF-LDHs. (c) As(V) uptake on $\mathrm{CO}_{3} @$ MF-LDHs and EDTA@MF-LDHs. (d) As $(\mathrm{V})$ removal efficiency on $\mathrm{CO}_{3} @ \mathrm{MF}-\mathrm{LDHs}$ and EDTA@MF-LDHs..

Preliminary studies revealed that the prepared EDTA@MF-LDHs adsorbent was more effective for both $\mathrm{As}(\mathrm{III})$ and $\mathrm{As}(\mathrm{V})$ removal than $\mathrm{CO}_{3} @ \mathrm{MF}-\mathrm{LDHs}$. Moreover, much more As(III) than As(V) could be adsorbed onto EDTA@MF-LDHs under the same experimental conditions. Thus, EDTA@MF-LDHs was selected for further As(III) removal study.

\subsubsection{Sorption Kinetics}

A series of kinetic models were used to fit the experimental data to investigate the sorption mechanism demonstrated. The pseudo-first-order and pseudo-second-order kinetic models are given in Equations (3) and (4):

$$
\begin{gathered}
\ln \left(q_{\mathrm{e}}-q_{\mathrm{t}}\right)=\ln q_{\mathrm{e}}-K_{1 \mathrm{t}} \\
\frac{t}{q_{\mathrm{t}}}=\frac{1}{k_{2} q_{\mathrm{e}}^{2}}+\frac{t}{q_{\mathrm{e}}}
\end{gathered}
$$

where $k_{1}$ and $k_{2}$ are the pseudo-first-order and pseudo-second-order constants ( $\left.\mathrm{g} /(\mathrm{mg} \cdot \mathrm{min})\right)$, respectively, $q_{\mathrm{t}}$ is the $\mathrm{As}(\mathrm{III})$ uptake at time $t(\mathrm{mg} / \mathrm{g})$ and $q_{\mathrm{e}}$ is the $\mathrm{As}(\mathrm{III})$ uptake at equilibrium $(\mathrm{mg} / \mathrm{g})$. The kinetics parameters obtained were summarized in Table 2 and Supplementary Table S2. The experimental data could be fitted to the pseudo-second-order kinetic model with $R^{2}=1.0000$ for $10 \mathrm{mg} / \mathrm{L} \mathrm{As}(\mathrm{III})$ and $R^{2}=0.9994$ for $50 \mathrm{mg} / \mathrm{L} \mathrm{As}(\mathrm{III})$, which was better than the fitting of the pseudo-first-order kinetic model $\left(R^{2}=0.8428\right.$ and 0.7649) (Figure 7), Elovich and Morris intra-particle diffusion models (Supplementary Figure S3). For the initial As(III) concentration of 10 and $50 \mathrm{mg} / \mathrm{L}$, the calculated As(III) uptakes at equilibrium $\left(q_{\mathrm{e}}\right)$ of $20.96 \mathrm{mg} / \mathrm{g}$ and $71.94 \mathrm{mg} / \mathrm{g}$ were well in agreement with the measured data of $20.95 \mathrm{mg} / \mathrm{g}$ and $71.98 \mathrm{mg} / \mathrm{g}$, respectively. The low $K_{2}$ value implied that the adsorption rate decreased with the increase in contact time and the adsorption rates were proportional to the number of adsorption sites. Therefore, the adsorption rates were controlled by chemisorption involving valence forces [60] and the As(III) adsorption capacity of EDTA@MF-LDHs depended mainly on the active sites on the material surface. On the other hand, according to the effect of contact time on As(III) adsorption onto EDTA@MF-LDHs shown in Supplementary Figure S3a, specific adsorption occurring between As(III) and EDTA@MF-LDHs, because adsorption solely due to electrostatic processes was usually in the order of seconds but not hours [58]. 
Table 2. Kinetics parameter for As(III) adsorption onto EDTA@MF-LDHs.

\begin{tabular}{|c|c|c|c|c|c|c|c|}
\hline \multirow{2}{*}{$\begin{array}{c}\text { Initial As(III) } \\
\text { Concentration } \\
(\mathrm{mg} / \mathrm{L})\end{array}$} & \multicolumn{3}{|c|}{ Pseudo-First-Order Constant } & \multicolumn{4}{|c|}{ Pseudo-Second-Order Constant } \\
\hline & $K_{1}(/ \min )$ & $q_{\mathrm{e}}(\mathrm{mg} / \mathrm{g})$ & $R^{2}$ & $k_{2}(\mathrm{~g} /(\mathrm{mg} \cdot \mathrm{min}))$ & $h(\mathrm{~g} /(\mathrm{mg} \cdot \mathrm{min}))$ & $q_{\mathrm{e}}(\mathrm{mg} / \mathrm{g})$ & $R^{2}$ \\
\hline 10 & 0.003 & 2.010 & 0.843 & 0.008 & 3.279 & 20.960 & 1.000 \\
\hline 50 & 0.004 & 17.780 & 0.765 & 0.001 & 4.684 & 71.940 & 0.999 \\
\hline
\end{tabular}
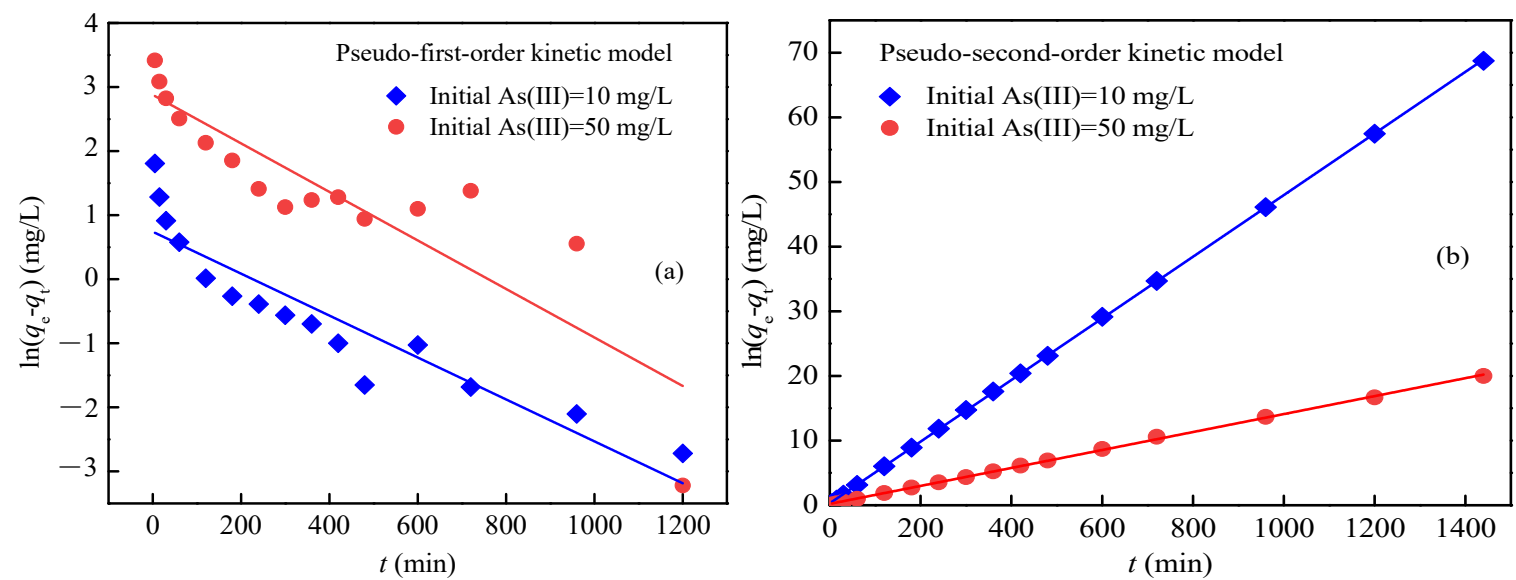

Figure 7. Kinetics isotherm for As(III) removal by EDTA@MF-LDHs.(pH $7.0 \pm 0.2$; temperature $25^{\circ} \mathrm{C}$ ).

(a) Pseudo-first-order kinetic model. (b) Pseudo-second-order kinetic model.

\subsubsection{Sorption Isotherms}

The adsorption results were fitted with the Langmuir and Freundlich isotherm models as given in Equations (5) and (6), respectively:

$$
\begin{gathered}
C_{\mathrm{e}} / q_{\mathrm{e}}=1 /\left(q_{\mathrm{m}} \cdot K_{\mathrm{L}}\right)+C_{\mathrm{e}} / q_{\mathrm{m}} \\
\ln q_{\mathrm{e}}=\ln K_{\mathrm{F}}+1 / n \ln C_{\mathrm{e}}
\end{gathered}
$$

where $q_{\mathrm{e}}$ is the amount $(\mathrm{mg} / \mathrm{g})$ of $\mathrm{As}(\mathrm{III})$ adsorbed at equilibrium, $C_{\mathrm{e}}$ is the equilibrium $\mathrm{As}(\mathrm{III})$ concentration $(\mathrm{mg} / \mathrm{L})$ in water samples, $K_{\mathrm{L}}$ and $q_{\max }$ (maximum adsorption capability) are the Langmuir constants, and $K_{\mathrm{F}}$ and $n$ are the Freundlich constants. The sorption isotherm fittings and the corresponding fitting parameters are reported in Figure 8 and Table 3, respectively. As can be observed, both isothermal models could well describe the isothermal adsorption process of As(III) onto EDTA@MF-LDHs with high fitted correlation coefficient $\left(R^{2}>0.92\right)$. The $R^{2}$ value of Freundlich isotherm model was slightly higher and the adsorption of As(III) onto EDTA@MF-LDHs belonged to the multi-layer adsorption on the inhomogeneous surface [1]. The value of parameter $1 / n$ can be used to characterize the nonlinear growth trend of adsorption [61]. The $1 / n$ value between 0.1 and 0.5 indicated that As(III) was easy adsorbed by EDTA@MF-LDHs. The maximum As(III) adsorption capacity $\left(q_{\mathrm{m}}\right)$ of EDTA@MF-LDHs was determined from the Langmuir model to be $68.49 \mathrm{mg} / \mathrm{g}$, and the reletive adsorption constant $K_{\mathrm{L}}$ from 0.734 to 1.186 , both the $q_{\mathrm{m}}$ and $K_{\mathrm{L}}$ are limilar to or slightly higher than many reported meterials, such as ferrous hydroxide colloids (FHC) [1], Mn-Fe-LDH [59], $\mathrm{Fe}_{3} \mathrm{O}_{4} / \mathrm{Cu}(\mathrm{OH})_{2}$ [62], aspartic acid intercalated $\mathrm{LDH}$ [63] and magnetic $\mathrm{Fe}_{3} \mathrm{O}_{4} @ \mathrm{CuO}$ nanocomposite [64], listed as in Table 4. This means that EDTA@MF-LDHs can be suitable adsorbent for the removal of As(III) from aqueous solution. An extremely high As(III) adsorption maxima of $0.58 \mathrm{~mol} \mathrm{As} / \mathrm{mol} \mathrm{Fe}$ $(778 \mathrm{mg} / \mathrm{g})$ for ferryhydrite (Raven et al., 1998) could be an experimental anomaly attributable to the high initial As(III) solution concentration of $26.7 \mathrm{mmol} / \mathrm{L}(2000 \mathrm{mg} / \mathrm{L})$ used in their studies [65]. 

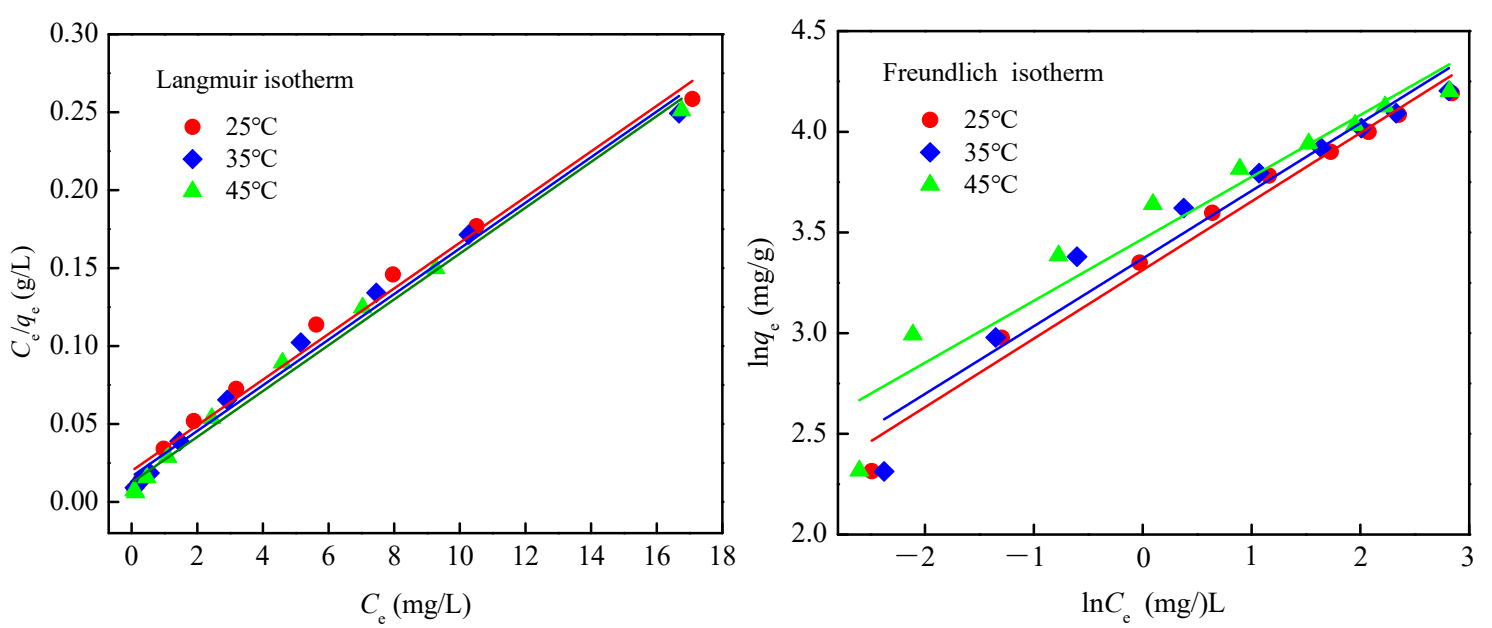

Figure 8. Isotherm for As(III) removal by EDTA@MF-LDHs. (initial concentration 5-50 mg/L; pH $7.0 \pm 0.2$; temperature $25-45^{\circ} \mathrm{C}$ ).

Table 3. Isotherm parameter for As(III) adsorption onto EDTA@MF-LDHs.

\begin{tabular}{|c|c|c|c|c|c|c|c|}
\hline \multirow[b]{2}{*}{ Temperature $\left({ }^{\circ} \mathrm{C}\right)$} & \multicolumn{4}{|c|}{ Langmuir Constant } & \multicolumn{3}{|c|}{ Freundlich Constant } \\
\hline & $q_{\mathrm{m}}(\mathrm{mg} / \mathrm{g})$ & $K_{\mathrm{L}}(\mathrm{L} / \mathrm{mg})$ & $R_{\mathrm{L}}$ & $R^{2}$ & $\underset{\left(\mathrm{mg}^{1-1 / n} \cdot \mathrm{L}^{1 / \mathrm{n}} / \mathrm{g}\right)}{K_{\mathrm{f}}}$ & $1 / n$ & $R^{2}$ \\
\hline 25 & 68.49 & 0.734 & $0.027-0.214$ & 0.986 & 27.481 & 0.341 & 0.979 \\
\hline 35 & 68.49 & 0.896 & $0.022-0.183$ & 0.989 & 29.093 & 0.336 & 0.942 \\
\hline 45 & 68.03 & 1.186 & $0.017-0.144$ & 0.992 & 28.413 & 0.308 & 0.917 \\
\hline
\end{tabular}

Table 4. Comparison of arsenic adsorption capacity between EDTA@MF-LDHs and other adsorbents.

\begin{tabular}{|c|c|c|c|c|c|}
\hline Adsorbents & emperature $\left({ }^{\circ} \mathrm{C}\right)$ & $\begin{array}{l}\text { Concentration } \\
\text { of } \operatorname{As}(\mathrm{III})(\mathrm{mg} / \mathrm{L})\end{array}$ & $Q_{\max }(\mathrm{mg} / \mathrm{g})$ & $K_{\mathrm{L}}(\mathrm{L} / \mathrm{mg})$ & Source \\
\hline Ferryhydrite & - & 2000 & 778 & - & [65] \\
\hline Ferryhydrite & 25 & 100 & 122.63 & 0.302 & [1] \\
\hline $\mathrm{Mn}-\mathrm{Fe}-\mathrm{LDH}$ & 45 & 100 & 113.12 & - & [59] \\
\hline $\mathrm{Fe}_{3} \mathrm{O}_{4} / \mathrm{Cu}(\mathrm{OH})_{2}$ & 25 & 85 & 37.97 & - & {$[62]$} \\
\hline $\mathrm{Mg}_{7} \mathrm{Zn}_{7} \mathrm{Fe}_{4}-\mathrm{Asp}-\mathrm{LDH}$ & 25 & 100 & 94.81 & 0.2664 & \multirow[t]{2}{*}{ [63] } \\
\hline $\mathrm{Mg}_{7} \mathrm{Zn}_{1} \mathrm{Fe}_{4}-\mathrm{Phe}-\mathrm{LDH}$ & 25 & 100 & 58.09 & 0.0988 & \\
\hline $\begin{array}{l}\mathrm{Fe}_{3} \mathrm{O}_{4} @ \mathrm{CuO} \\
\mathrm{Fe} @ \mathrm{Cu} \& \mathrm{GO}\end{array}$ & $\begin{array}{l}25 \\
25\end{array}$ & 75 & $\begin{array}{l}50.58 \\
70.36\end{array}$ & $\begin{array}{l}0.058 \\
0.182\end{array}$ & [64] \\
\hline 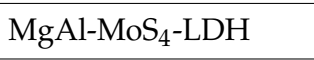 & 25 & 400 & 99 & - & [66] \\
\hline EDTA@MF-LDHs & $\begin{array}{l}25 \\
35 \\
45\end{array}$ & 50 & $\begin{array}{l}68.49 \\
68.49 \\
68.03\end{array}$ & $\begin{array}{l}0.734 \\
0.896 \\
1.186\end{array}$ & This study \\
\hline
\end{tabular}

Note:"-" means no data.

\subsubsection{Removal Mechanisms}

To insight into the sorption mechanism of As(III) by EDTA@MF-LDHs, a matrix of complimentary analyses were performed. First, the FT-IR spectra of $\mathrm{CO}_{3} @$ MF-LDHs and EDTA@MF-LDHs before and after sorption are exhibited in Figure 3. After $\mathrm{CO}_{3} @$ MF-LDHs adsorbed As(III) (a2), the vibration peak of $\mathrm{CO}_{3}{ }^{2-}\left(1384 \mathrm{~cm}^{-1}\right)$ did not disappear and the peak position almost did not shift. This may be due to the strong binding force between $\mathrm{CO}_{3}{ }^{2-}$ and the metal laminate, which makes it difficult to exchange with the anions in the aqueous solution, so the vibration peak of carbonate $\left(1384 \mathrm{~cm}^{-1}\right)$ still exists. After As(III) adsorption on EDTA@MF-LDHs (b2), the adsorbent still showed a strong and 
wide diffraction peak of -OH in the range of $3200-3500 \mathrm{~cm}^{-1}$, but it shifted slightly to low frequency, which might be attributed to the electrostatic attraction between the protonated oxygen-containing groups and anions [59]. There was a strong shoulder peak at $784 \mathrm{~cm}^{-1}$ after As(III) adsorption, which was inferred as the Fe-As-O and Mn-As-O bonds, indicating that As(III) was effectively adsorbed to form an inner complex on the surface of the adsorbent. In addition, the characteristic peaks at $548 \mathrm{~cm}^{-1}$, corresponding to the metal lattice, shifted to a low frequency $515 \mathrm{~cm}^{-1}$ after As(III) adsorption. Therefore, $\mathrm{Fe}-\mathrm{O}$ and $\mathrm{Mn}-\mathrm{O}$ bonds were also involved in the adsorption process with a new characteristic peak of As-O-As appeared. The peak position of the $\mathrm{C}=\mathrm{O}$ functional bonds in the carboxyl group moved from $1625 \mathrm{~cm}^{-1}$ to $1636 \mathrm{~cm}^{-1}$ and the peak at $1113 \mathrm{~cm}^{-1}$ disappeared after As(III) adsorption, which indicated that [EDTA $]^{4-}$ participated in the adsorption process through $\mathrm{C}=\mathrm{O}$ and C-N groups $[38,66]$. After As(III) adsorption by EDTA@MF-LDHs, there was an obvious characteristic peak at $1384 \mathrm{~cm}^{-1}$ corresponding to $\left[\mathrm{CO}_{3}\right]^{2-}$, which might be introduced in the adsorption process.

The reported studies have confirmed that the test conditions of XPS (heating and vacuum) have no influence on the state of As $[24,67,68]$. The chemical compositions of EDTA@MF-LDHs before and after As(III) adsorption were further probed by XPS analyses in this stdudy. The main peaks of Fe2p, Mn2 $p, \mathrm{C} 1 s, \mathrm{O} 1 s$, and N1s were detected in the XPS full spectra before and after adsorption (Figure 9). The existence of the N1s peak further proved the existence of [EDTA] ${ }^{4-}$. The As3d peak (44.1-45.6 eV) in the spectrum of the sample after As(III) adsorption confirmed that As(III) was adsorbed on EDTA@MF-LDHs. In order to reveal more accurately the chemical forms of EDTA@MF-LDHs after $\mathrm{As}(\mathrm{III})$ adsorption, the high-resolution spectra of $\mathrm{As}, \mathrm{Fe}, \mathrm{O}$, and $\mathrm{C}$ before and after adsorption were further analyzed with the corresponding peak fitting as shown in Figure 9b-e. It was found that there were both trivalent arsenic $(44.2 \mathrm{eV})$ and pentavalent arsenic $(45.4 \mathrm{eV})$ peaks in the As3d spectrum after $\mathrm{As}(\mathrm{III})$ adsorption, indicating that $\mathrm{As}(\mathrm{III})$ was partially oxidized to As(V) during the adsorption (Figure 9b).

As shown in Figure 9c, the binding energy of Fe2 $p$ shifted from $711.11 \mathrm{eV}$ to $711.19 \mathrm{eV}$ after As(III) adsorption. The shifting of binding energy indicated that the physical and chemical environment around the Fe element in EDTA@MF-LDHs had changed. The co-existence of Fe(III) and Fe(II) after As(III) adsorption might be related to the redox interaction between $\mathrm{Fe}(\mathrm{III})$ and $\mathrm{As}$ (III). The spectra of O1s showed the additional As-O peaks and the peak area assigned to $\mathrm{C}-\mathrm{O} / \mathrm{C}=\mathrm{O}$ and $\mathrm{O}-\mathrm{H}$ decreased after As(III) adsorption (Figure 9d), reflecting a decrease in their quantity. After As(III) adsorption, the characteristic peaks of the $\mathrm{C} 1 s$ spectra shifted from $284.44 \mathrm{eV}$ to $284.54 \mathrm{eV}$ and the peak intensities decreased noticeably (Figure 9e). We speculated that the oxidized As(V) was exchanged with interlayer $[\mathrm{EDTA}]^{4-}$ and surface hydroxyl functional groups.

Based on the above analysis, the mechanism of As(III) adsorption onto EDTA@MF-LDHs was a complicated process including surface complexation, redox, and ion exchange (Figure 10). In the solution of $\mathrm{pH}=7, \mathrm{As}(\mathrm{III})$ existed mainly as a neutral molecule $\left(\mathrm{H}_{3} \mathrm{AsO}_{3}\right)$, which could exchange ligands with the plentiful hydroxyl groups on the surface of the metal laminates, and then As(III) was oxidized to $\mathrm{As}(\mathrm{V})$ by $\mathrm{Fe}(\mathrm{III})$ around $\mathrm{pH}=4.55 \sim 12, \mathrm{Mn}(\mathrm{II}) / \mathrm{Fe}(\mathrm{III})-\mathrm{OH}$ was reduced to $2 \equiv \mathrm{Mn}(\mathrm{II}) / \mathrm{Fe}(\mathrm{II})-\mathrm{O}^{-}$ (Figure 9d), so it is negative charge on the EDTA@MF-LDHs surface (Figure 4), Mn(II) is the structural carrier of bimetallic hydroxide. The oxidizing reaction process as follows:

$$
\begin{gathered}
2 \equiv \mathrm{Mn} / \mathrm{Fe}-\mathrm{OH}+\mathrm{H}_{3} \mathrm{AsO}_{3}+\mathrm{H}_{2} \mathrm{O} \rightarrow 2 \equiv \mathrm{Mn} / \mathrm{Fe}-\mathrm{OH}^{+}+\mathrm{HAsO}_{4}^{-}+\mathrm{H}_{2} \mathrm{O} \\
2 \equiv \mathrm{Mn} / \mathrm{Fe}-\mathrm{O}+\mathrm{H}_{3} \mathrm{AsO}_{3}+\mathrm{H}_{2} \mathrm{O} \rightarrow 2 \equiv \mathrm{Mn} / \mathrm{Fe}-\mathrm{O}^{+}+\mathrm{HAsO}_{4}^{-}+\mathrm{H}_{2} \mathrm{O}
\end{gathered}
$$

Meanwhile, As $(\mathrm{V})$ could be further exchanged with interlayer anions including $\mathrm{Cl}^{-}$and $[\mathrm{EDTA}]^{4-}$. The ion exchange between arsenate ions and $\mathrm{Cl}^{-}$could be distinctly confirmed by the EDS result (Supplementary Table S3). $\mathrm{Cl}^{-}$could not be detected on the surface of the adsorbent after adsorption. 

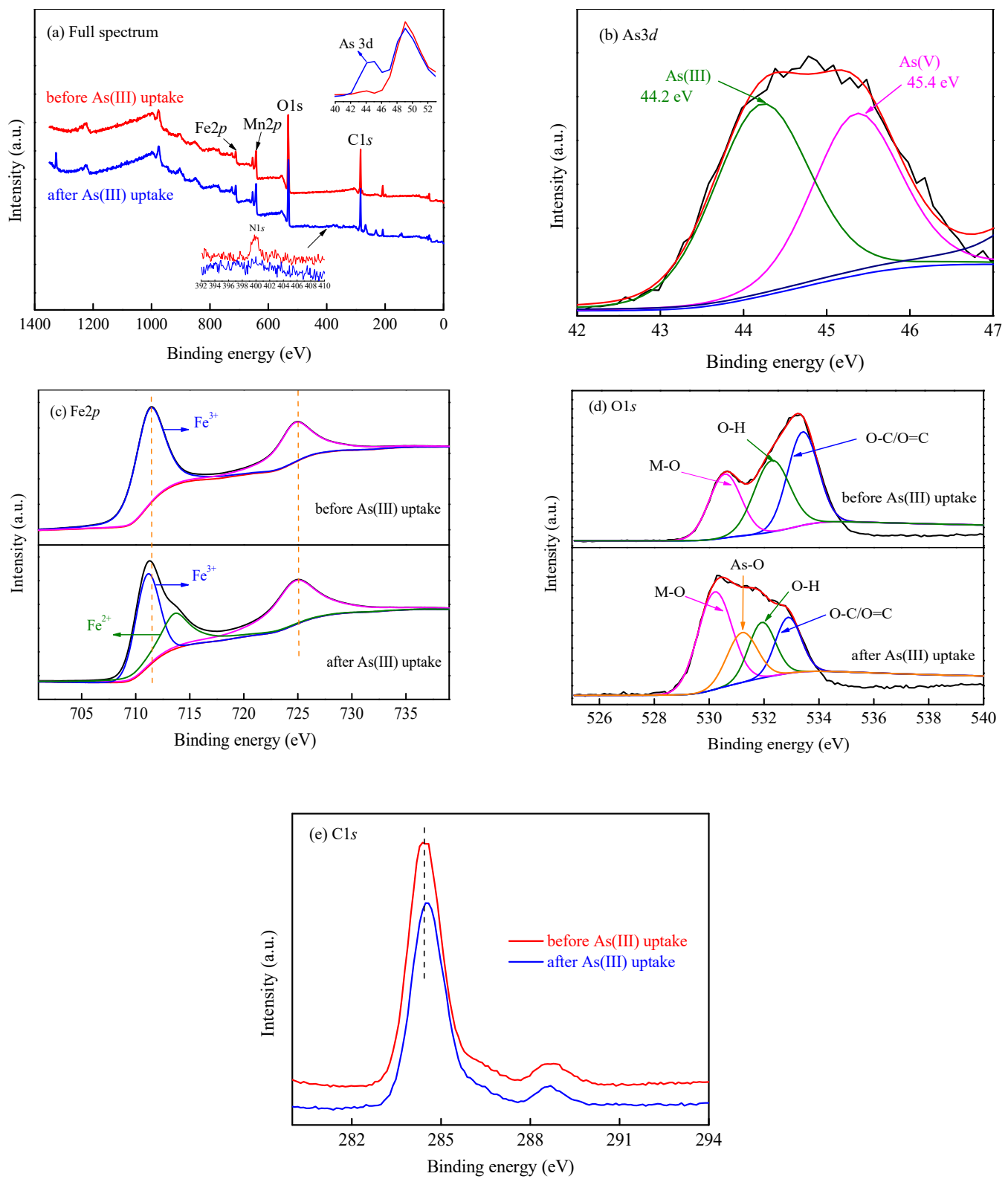

Figure 9. XPS spectral of (a) Full spectrum, (b) As3d, (c) Fe2p, (d) O1s, and (e) C1s for EDTA@MF-LDHs before and after As(III) adsorption (initial concentration $50 \mathrm{mg} / \mathrm{L}$ ).

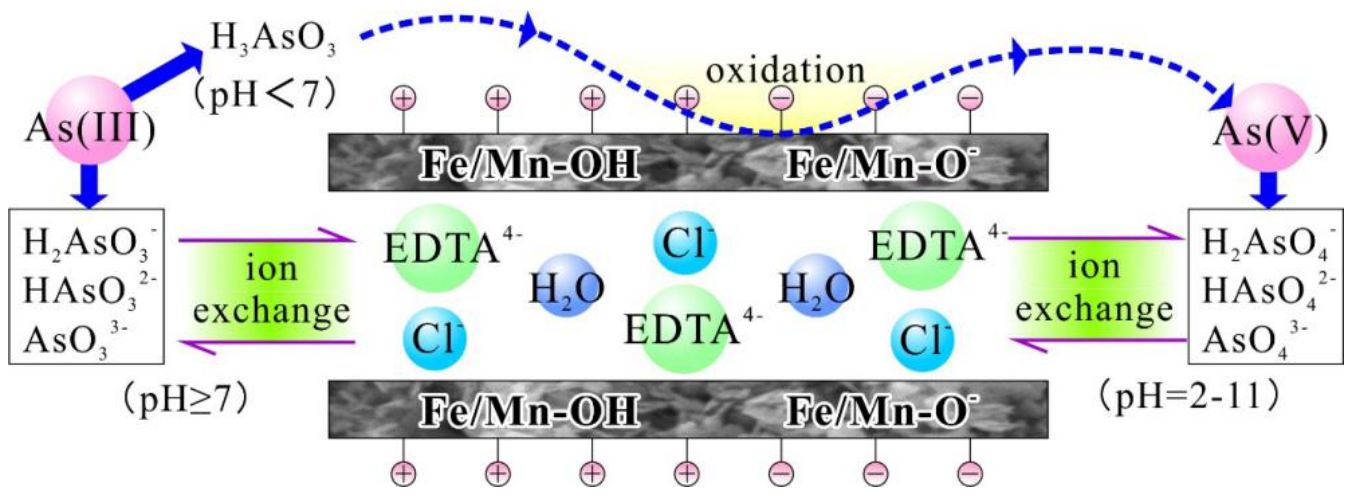

Figure 10. Mechanism of As(III) elimination by EDTA@MF-LDHs. 


\subsubsection{Material Stability Test}

In this experiment, the chemical stability of EDTA@MF-LDH was discussed. The results showed that nearly no iron ion was detected in the solution after As (III) adsorption, but manganese ion was dissolved, and at $\mathrm{pH} 11$, the concentration of manganese ion is below $10 \mathrm{mg} / \mathrm{L}$. It can also be seen that the concentration of As(III) has no obvious effect on the dissolution of iron and manganese. The change trend of manganese concentration in solution corresponds to that of As(III) adsorption on EDTA@MF-LDH (Figure 5). The specific results are shown in Figure 11.

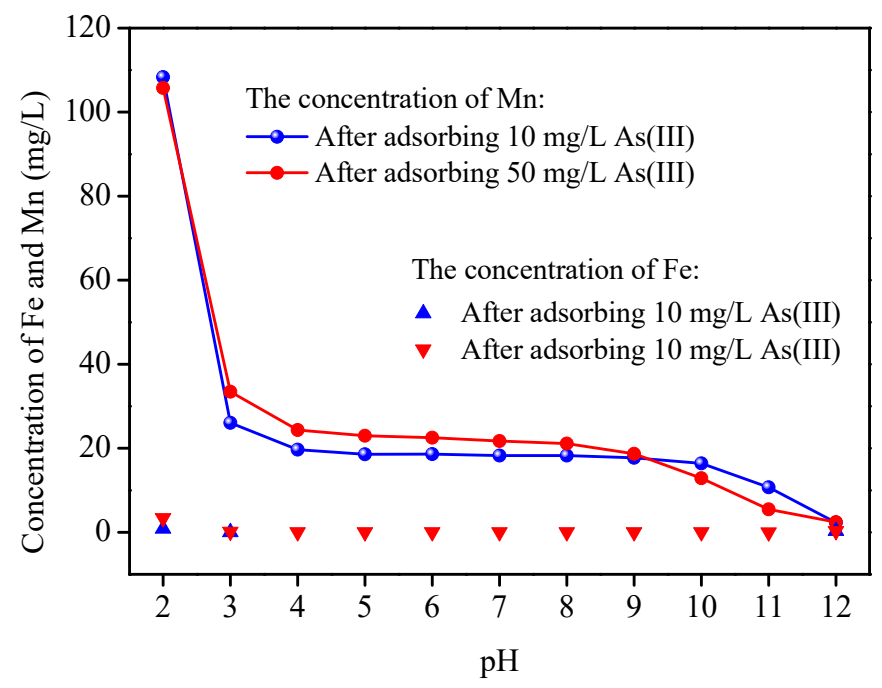

Figure 11. The stability test of EDTA@MF-LDH after As(III) adsorption. (adsorbent dose $0.5 \mathrm{~g} / \mathrm{L}$; $\mathrm{pH} 7.0 \pm 0.2$; temperature $25 \pm 1^{\circ} \mathrm{C}$ ).

\section{Conclusions}

A novel and highly efficient adsorbent, EDTA@MF-LDHs with the lamellar structure, was first designed for the application of As(III) removal. Compared with $\mathrm{CO}_{3} @ M F-L D H s, E D T A @ M F-L D H s$ showed a higher interlayer spacing $0.804 \mathrm{~nm}$, which was helpful for As(III) to enter the interlayer of LDHs for ion exchange. EDTA@MF-LDHs had a high adsorption capacity for As(III) in a wide $\mathrm{pH}$ range of 2 to 11 . When the dosage of EDTA@MF-LDHs was $0.5 \mathrm{~g} / \mathrm{L}$, the removal efficiency of As(III) $(10 \mathrm{mg} / \mathrm{L})$ was maintained at a level above $97 \%$. The adsorption capacities of EDTA@MF-LDHs towards As(III) were $68.49 \mathrm{mg} / \mathrm{g}$ determined from the Langmuir model, which is similar to or slightly higher than many reported adsorbents (Table 4). We also found that As(III) could be oxidized to As(V) by EDTA@MF-LDHs directly without adding any oxidant. This reduced the pollution toxicity as well as promoted ion exchange. In the EDTA@MF-LDHs-As(III) systems, the As(III) adsorption removal mechanism includes surface complexation, redox, and ion exchange. Remarkably, this work provides a strategy for As(III) removal adsorbent MF-LDHs (metal laminates were derived from transition metals) synthesis. Meanwhile, it also provides a clearer understanding of adsorption mechanisms which would be beneficial for further design of related adsorbent.

Supplementary Materials: The following are available online at http://www.mdpi.com/1660-4601/17/24/9341/s1, Figure S1: Effect of $\mathrm{pH}$ on the residual concentration of 10 and $50 \mathrm{mg} / \mathrm{L} \mathrm{As}(\mathrm{III} / \mathrm{V})$ stock solution (temperature $25 \pm 1^{\circ} \mathrm{C}$ ), Figure S2: As(III) species with the change of the solution $\mathrm{pH}(\mathrm{As}(\mathrm{III})=50 \mathrm{mg} / \mathrm{L}$; chloride ion strength of $0.01 \mathrm{~mol} / \mathrm{L})$, Figure S3: Effect of contact time on As(III) adsorption onto EDTA@MF-LDHs. (a): Fitting with Elovich kinetic model; (b): Fitting with the Morris intra-particle diffusion model; (c): Initial As(III) concentration 10 and $50 \mathrm{mg} / \mathrm{L}$; sorbent dose $0.5 \mathrm{~g} / \mathrm{L} ; \mathrm{pH} 7.0 \pm 0.2$; temperature $25 \pm 1{ }^{\circ} \mathrm{C}$, Table S1: EDS analysis of EDTA@MF-LDHs before and after As(III) adsorption (\%), Table S2 Kinetics parameter for As(III) adsorption onto EDTA@MF-LDHs.

Author Contributions: Conceptualization and study design: Z.Z. and Y.Z.; operation and software: G.L., Y.G. and L.Z.; literature collection: N.Z. and Y.F.; manuscript writing G.L.; writing-review: Z.Z.; All authors have read and agreed to the published version of the manuscript. 
Funding: This work was financially supported by the National Natural Science Foundation of China (Nos. 21707024, 41763012 and 2019YFC0507502), the Guangxi Science and Technology Planning Project (Nos. GuiKe-AD18126018, GuiKeAA 17204047), the Guangxi Natural Science Foundation (2018GXNSFAA050044), Chinese Postdoctoral Science Foundation (No. 2019M650869), Technical Innovation Center of Mine Geological Environmental Restoration Enginneering in Southern Karst Area and the Special Fund for Guangxi Distinguished Experts.

Conflicts of Interest: The authors declare no conflict of interest.

\section{References}

1. Wen, Z.P.; Zhang, Y.L.; Zhou, X.F.; Chen, R. Effective As (III) and As (V) immobilization from aqueous solution by nascent ferrous hydroxide colloids (FHC). Sep. Purif. Technol. 2017, 176, 395-401. [CrossRef]

2. Bai, Y.H.; Yang, T.T.; Liang, J.S.; Qu, J.H. The role of biogenic Fe-Mn oxides formed in situ for arsenic oxidation and adsorption in aquatic ecosystems. Water Res. 2016, 98, 119-127. [CrossRef] [PubMed]

3. Bamidele, E.A.; Makhatha, M.E.; Nheta, W. A Review of Lanthanum Nanoparticles Impregnated Compound Arsenic Fixation kinetics in Copper Aqueous Solution. In Paper 170 at Technologies E Materials for Renewable Energy, Environment \& Sustainability; Elsevier: Amsterdam, The Netherlands, 2018.

4. Sheng, T.T.; Baig, S.A.; Hu, Y.J.; Xue, X.Q.; Xu, X.H. Development, characterization and evaluation of iron-coated honeycomb briquette cinders for the removal of As (V) from aqueous solutions. Arab. J. Chem. 2014, 7, 27-36. [CrossRef]

5. Zhou, Y.Z.; Zeng, Y.Y.; Zhou, J.L.; Guo, H.M.; Li, Q.; Jia, R.L.; Chen, Y.F.; Zhao, J.T. Distribution of groundwater arsenic in Xinjiang, PR China. Appl. Geochem. 2017, 77, 116-125. [CrossRef]

6. Asere, T.G.; Stevens, C.V.; Laing, G.D. Use of (modified) natural adsorbents for arsenic remediation: A review. Sci. Total Environ. 2019, 676, 706-720. [CrossRef]

7. Bapkan, M.B.; Pala, A.; Türkman, A. Türkman, Arsenate removal by coagulation using iron salts and organic polymers. Ekoloji 2010, 19, 69-76.

8. Sankpal, U.T.; Pius, H.; Khan, M.; Shukoor, M.I.; Maliakal, P.; Lee, C.M.; Abdelrahim, M.; Connelly, S.F.; Basha, R. Environmental factors in causing human cancers: Emphasis on tumorigenesis. Tumor. Biol. 2012, 33, 1265-1274. [CrossRef]

9. Xu, Z.; Li, Q.; Gao, S.; Shang, J.K. As (III) removal by hydrous titanium dioxide prepared from one-step hydrolysis of aqueous TiCl4 solution. Water Res. 2010, 44, 5713-5721. [CrossRef]

10. Mohan, D.; Pittman, C.U., Jr. Arsenic removal from water/wastewater using adsorbents-A critical review. J. Hazard. Mater. 2007, 142, 1-53. [CrossRef]

11. Borho, M.; Wilderer, P. Optimized removal of arsenate (III) by adaptation of oxidation and precipitation processes to the filtration step. Water Sci. Technol. 1996, 34, 25-31. [CrossRef]

12. Lee, $\mathrm{H}$.; Choi, W. Photocatalytic oxidation of arsenite in $\mathrm{TiO}_{2}$ suspension: Kinetics and mechanisms. Environ. Sci. Technol. 2002, 36, 3872-3878. [CrossRef] [PubMed]

13. Kim, Y.; Kim, C.; Choi, I.; Rengaraj, S.; Yi, J. Arsenic removal using mesoporous alumina prepared via a templating method. Environ. Sci. Technol. 2004, 38, 924-931. [CrossRef] [PubMed]

14. Cheng, Z.; Fu, F.; Dionysiou, D.D.; Tang, B. Adsorption, oxidation, and reduction behavior of arsenic in the removal of aqueous As (III) by mesoporous Fe/Al bimetallic particles. Water Res. 2016, 96, 22-31. [CrossRef] [PubMed]

15. Du, Q.; Zhang, S.; Pan, B.; Lv, L.; Zhang, W.; Zhang, Q. Bifunctional resin-ZVI composites for effective removal of arsenite through simultaneous adsorption and oxidation. Water Res. 2013, 47, 6064-6074. [CrossRef] [PubMed]

16. Bissen, M.; Frimmel, F.H. Arsenic-A review. Part I: Occurrence, toxicity, speciation, mobility. Acta Hydroch. Hydrob. 2003, 31, 9-18. [CrossRef]

17. Abdul, K.S.M.; Jayasinghe, S.S.; Chandana, E.P.; Jayasumana, C.; De Silva, P.M.C. Arsenic and human health effects: A review. Environ. Toxicol. Pharmacol. 2015, 40, 828-846. [CrossRef]

18. Goh, K.H.; Lim, T.T.; Dong, Z.L. Enhanced Arsenic Removal by Hydrothermally Treated Nanocrystalline Mg/Al Layered Double Hydroxide with Nitrate Intercalation. Environ. Sci. Technol. 2009, 43, 2537-2543. [CrossRef]

19. Wang, S.; Gao, B.; Li, Y. Enhanced arsenic removal by biochar modified with nickel (Ni) and manganese (Mn) oxyhydroxides. J. Ind. Eng. Chem. 2016, 37, 361-365. [CrossRef] 
20. Wang, S.; Gao, B.; Li, Y.; Zimmerman, A.R.; Cao, X. Sorption of arsenic onto Ni/Fe layered double hydroxide (LDH)-biochar composites. RSC Adv. 2016, 6, 17792-17799. [CrossRef]

21. Yue, X.; Liu, W.; Chen, Z.; Lin, Z. Simultaneous removal of $\mathrm{Cu}$ (II) and Cr (VI) by Mg-Al-Cl layered double hydroxide and mechanism insight. J. Environ. Sci. 2017, 53, 16-26. [CrossRef]

22. Kameda, T.; Saito, S.; Umetsu, Y. Mg-Al layered double hydroxide intercalated with ethylenediaminetetraacetate anion: Synthesis and application to the uptake of heavy metal ions from an aqueous solution. Sep. Purif. Technol. 2005, 47, 20-26. [CrossRef]

23. Liu, P.; Liu, H.; Li, Y.; Dong, C. Remediation of arsenic contaminated soils and treatment of washing effluent using calcined Mn-Fe Layered double hydroxide. Adv. Mater. 2014, 955-959, 2014-2021. [CrossRef]

24. Wu, X.L.; Tan, X.L.; Yang, S.T.; Wen, T.; Guo, H.L.; Wang, X.K.; Xu, A.W. Coexistence of adsorption and coagulation processes of both arsenate and NOM from contaminated groundwater by nanocrystallined Mg/Al layered double hydroxides. Water Res. 2013, 47, 4159-4168. [CrossRef] [PubMed]

25. Zhang, X.L.; Guo, L.; Huang, H.; Jiang, Y.H.; Li, M.; Leng, Y.J. Removal of phosphorus by the core-shell bio-ceramic/Zn-layered double hydroxides (LDHs) composites for municipal wastewater treatment in constructed rapid infiltration system. Water Res. 2016, 96, 280-291. [CrossRef]

26. Jiang, J.Q.; Ashekuzzaman, S.M.; Hargreaves, J.S.J.; McFarlane, A.R.; Badruzzamanc, A.B.M.; Tarekc, M.H. Removal of Arsenic (III) from groundwater applying a reusable $\mathrm{Mg}-\mathrm{Fe}-\mathrm{Cl}$ layered double hydroxide. J. Chem. Technol. Biotechnol 2015, 90, 1160-1166. [CrossRef]

27. Evans, D.G.; Slade, R.C. Structural aspects of layered double hydroxides. In Layered Double Hydroxides; Springer: Berlin/Heidelberg, Germany, 2006; pp. 1-87.

28. Williams, G.R.; Khan, A.I.; O'Hare, D. Mechanistic and kinetic studies of guest ion intercalation into layered double hydroxides using time-resolved, in-situ X-ray powder diffraction. In Layered Double Hydroxides; Springer: Berlin/Heidelberg, Germany, 2006; pp. 161-192.

29. Taylor, H. Segregation and cation-ordering in sjögrenite and pyroaurite. Mineral. Mag. 1969, 37, 338-342. [CrossRef]

30. Allmann, R. The crystal structure of pyroaurite. Acta Crystallogr. B 1968, 24, 972-977. [CrossRef]

31. Nakayama, H.; Hirami, S.; Tsuhako, M. Selective adsorption of mercury ion by mercaptocarboxylic acid intercalated Mg-Al layered double hydroxide. J. Colloid Interface Sci. 2017, 315, 177-183. [CrossRef]

32. Pavlovic, I.; Pérez, M.; Barriga, C.; Ulibarri, M. Adsorption of $\mathrm{Cu}^{2+}, \mathrm{Cd}^{2+}$ and $\mathrm{Pb}^{2+}$ ions by layered double hydroxides intercalated with the chelating agents diethylenetriaminepentaacetate and meso-2, 3-dimercaptosuccinate. Appl. Clay Sci. 2009, 43, 125-129. [CrossRef]

33. Liang, X.; Hou, W.; Xu, Y.; Sun, G.; Wang, L.; Sun, Y.; Qin, X. Sorption of lead ion by layered double hydroxide intercalated with diethylenetriaminepentaacetic acid. Colloid Surf. A 2010, 366, 50-57. [CrossRef]

34. Zhang, G.; Liu, H.; Qu, J.; Jefferson, W. Arsenate uptake and arsenite simultaneous sorption and oxidation by Fe-Mn binary oxides: Influence of $\mathrm{Mn} / \mathrm{Fe}$ ratio, $\mathrm{pH}, \mathrm{Ca}^{2+}$, and humic acid. J. Colloid Interface Sci. 2012, 366, 141-146. [CrossRef] [PubMed]

35. Deschamps, E.; Ciminelli, V.S.; Höll, W.H. Removal of As (III) and As (V) from water using a natural Fe and Mn enriched sample. Water Res. 2005, 39, 5212-5220. [CrossRef] [PubMed]

36. Wu, P.; Zhou, J.; Wang, X.; Dai, Y.; Dang, Z.; Zhu, N.; Li, P.; Wu, J. Adsorption of Cu-EDTA complexes from aqueous solutions by polymeric Fe/Zr pillared montmorillonite: Behaviors and mechanisms. Desalination 2011, 277, 288-295. [CrossRef]

37. Rojas, R.; Perez, M.R.; Erro, E.M.; Ortiz, P.I.; Ulibarri, M.A.; Giacomelli, C.E. EDTA modified LDHs as Cu ${ }^{2+}$ scavengers: Removal kinetics and sorbent stability. J. Colloid Interface Sci. 2009, 331, 425-431. [CrossRef]

38. Deng, L.; Shi, Z.; Wang, L.; Zhou, S. Fabrication of a novel $\mathrm{NiFe}_{2} \mathrm{O}_{4} / \mathrm{Zn}$-Al layered double hydroxide intercalated with EDTA composite and its adsorption behavior for $\mathrm{Cr}$ (VI) from aqueous solution. J. Phys. Chem. Solids 2017, 104, 79-90. [CrossRef]

39. Kameda, T.; Hoshi, K.; Yoshioka, T. Preparation of $\mathrm{Cu}-\mathrm{Al}$ layered double hydroxide intercalated with ethylenediaminetetraacetate by coprecipitation and its uptake of rare earth ions from aqueous solution. Solid State Sci. 2013, 17, 28-34. [CrossRef]

40. Chen, H.; Sun, Y.; Ruan, X.; Yu, Y.; Zhu, M.; Zhang, J.; Zhou, J.; Xu, Y.; Liu, J.; Qian, G. Advanced treatment of stabilized landfill leachate after biochemical process with hydrocalumite chloride (Ca/Al-Cl LDH). Bioresour. Technol. 2016, 210, 131-137. [CrossRef] 
41. Gao, H.; Song, Z.; Zhang, W.; Yang, X.; Wang, X.; Wang, D. Synthesis of highly effective absorbents with waste quenching blast furnace slag to remove Methyl Orange from aqueous solution. J. Environ. Sci. 2017, 53, 68-77. [CrossRef]

42. Abderrazek, K.; Frini Srasra, N.; Srasra, E. Synthesis and Characterization of [Zn-Al] Layered Double Hydroxides: Effect of the Operating Parameters. J. Chin. Chem. Soc. 2017, 64, 346-353. [CrossRef]

43. Das, J.; Patra, B.S.; Baliarsingh, N.; Parida, K. Calcined Mg-Fe- $\mathrm{CO}_{3} \mathrm{LDH}$ as an adsorbent for the removal of selenite. J. Colloid Interface Sci. 2007, 316, 216-223. [CrossRef]

44. Yan, D.; Lu, J.; Wei, M.; Ma, J.; Evans, D.G.; Duan, X. A combined study based on experiment and molecular dynamics: Perylene tetracarboxylate intercalated in a layered double hydroxide matrix. Phys. Chem. Chem. Phys. 2009, 11, 9200-9209. [CrossRef] [PubMed]

45. Bontchev, R.P.; Liu, S.; Krumhansl, J.L.; Voigt, J.; Nenoff, T.M. Synthesis, characterization, and ion exchange properties of hydrotalcite $\mathrm{Mg}_{6} \mathrm{Al}_{2}(\mathrm{OH}) 16(\mathrm{~A}) \times\left(\mathrm{A}^{\prime}\right) 2-\mathrm{x} \cdot 4 \mathrm{H}_{2} \mathrm{O}\left(\mathrm{A}, \mathrm{A}^{\prime}=\mathrm{Cl}^{-}, \mathrm{Br}^{-}, \mathrm{I}^{-}\right.$, and $\left.\mathrm{NO}_{3}^{-}, 2 \geq \mathrm{x} \geq 0\right)$ derivatives. Chem. Mater. 2003, 15, 3669-3675. [CrossRef]

46. Zhu, J.; Liu, Q.; Liu, J.; Chen, R.; Zhang, H.; Li, R.; Wang, J. Ni-Mn LDH-decorated 3D Fe-inserted and $\mathrm{N}$-doped carbon framework composites for efficient uranium (VI) removal. Environ. Sci. Nano 2018, 5, 467-475. [CrossRef]

47. Su, Q.; Gu, L.; Yao, Y.; Zhao, J.; Ji, W.; Ding, W.; Au, C.T. Layered double hydroxides derived Nix(MgyAlzOn) catalysts: Enhanced ammonia decomposition by hydrogen spillover effect. Appl. Catal. B-Environ. 2017, 201, 451-460. [CrossRef]

48. Aisawa, S.; Hirahara, H.; Uchiyama, H.; Takahashi, S.; Narita, E. Synthesis and thermal decomposition of Mn-Al layered double hydroxides. J. Solid State Chem. 2002, 167, 152-159. [CrossRef]

49. Pena, M.E.; Korfiatis, G.P.; Patel, M.; Lippincott, L.; Meng, X. Adsorption of As (V) and As (III) by nanocrystalline titanium dioxide. Water Res. 2005, 39, 2327-2337. [CrossRef]

50. Wang, T.; Li, C.; Wang, C.; Wang, H. Biochar/MnAl-LDH composites for Cu (II) removal from aqueous solution. Colloid Surf. A 2018, 538, 443-450. [CrossRef]

51. Chen, H.; Lin, J.; Zhang, N.; Chen, L.; Zhong, S.; Wang, Y.; Zhang, W.; Ling, Q. Preparation of MgAl-EDTA-LDH based electrospun nanofiber membrane and its adsorption properties of copper (II) from wasteWater. J. Hazard. Mater. 2018, 345, 1-9. [CrossRef]

52. Huang, Y.; Keller, A.A. EDTA functionalized magnetic nanoparticle sorbents for cadmium and lead contaminated water treatment. Water Res. 2015, 80, 159-168. [CrossRef]

53. Guo, X.; Liu, X.; Hao, X.; Zhu, S.; Dong, F.; Wen, Z.; Zhang, X. Nickel-manganese layered double hydroxide nanosheets supported on nickel foam for high-performance supercapacitor electrode materials. Electrochim. Acta 2016, 194, 179-186. [CrossRef]

54. Hao, H.; Liu, G.; Wang, Y.; Shi, B.; Han, K.; Zhuang, Y.; Kong, Y. Simultaneous cationic Cu (II)-anionic Sb (III) removal by $\mathrm{NH}_{2}-\mathrm{Fe}_{3} \mathrm{O}_{4}$-NTA core-shell magnetic nanoparticle sorbents synthesized via a facile one-pot approach. J. Hazard. Mater. 2019, 362, 246-257. [CrossRef] [PubMed]

55. Adeleke, J.; Theivasanthi, T.; Thiruppathi, M.; Swaminathan, M.; Akomolafe, T.; Alabi, A. Photocatalytic degradation of methylene blue by $\mathrm{ZnO} / \mathrm{NiFe}_{2} \mathrm{O}_{4}$ nanoparticles. Appl. Surf. Sci. 2018, 455, 195-200. [CrossRef]

56. Chandra, V.; Park, J.; Chun, Y.; Lee, J.W.; Hwang, I.C.; Kim, K.S. Water-dispersible magnetite-reduced graphene oxide composites for arsenic removal. ACS Nano 2010, 4, 3979-3986. [CrossRef] [PubMed]

57. Shan, C.; Ma, Z.; Tong, M. Efficient removal of trace antimony (III) through adsorption by hematite modified magnetic nanoparticles. J. Hazard. Mater. 2014, 268, 229-236. [CrossRef]

58. Hong, J.; Zhu, Z.; Lu, H.; Qiu, Y. Synthesis and arsenic adsorption performances of ferric-based layered double hydroxide with $\alpha$-alanine intercalation. Chem. Eng. J. 2014, 252, 267-274. [CrossRef]

59. Otgonjargal, E.; Kim, Y.S.; Park, S.-M.; Baek, K.; Yang, J.S. Mn-Fe layered double hydroxides for adsorption of As (III) and As (V). Sep. Purif. Technol. 2012, 47, 2192-2198.

60. Foo, K.; Hameed, B. Preparation, characterization and evaluation of adsorptive properties of orange peel based activated carbon via microwave induced $\mathrm{K}_{2} \mathrm{CO}_{3}$ activation. Bioresour. Technol. 2012, 104, 679-686. [CrossRef]

61. Crini, G. Kinetic and equilibrium studies on the removal of cationic dyes from aqueous solution by adsorption onto a cyclodextrin polymer. Dyes Pigment. 2008, 77, 415-426. [CrossRef]

62. Wang, T.; Yang, W.; Song, T.; Li, C.; Zhang, L.; Wang, H.; Chai, L. Cu doped $\mathrm{Fe}_{3} \mathrm{O}_{4}$ magnetic adsorbent for arsenic: Synthesis, property, and sorption application. RSC Adv. 2015, 5, 50011-50018. [CrossRef] 
63. Lu, H.; Lu, T.; Zhang, H.; Qiu, Y.; Yin, D.; Zhu, Z. Enhanced adsorption performance of aspartic acid intercalated Mg-Zn-Fe-LDH materials for arsenite. Dalton Trans. 2018, 47, 4994-5004. [CrossRef]

64. Wu, K.; Jing, C.; Zhang, J.; Liu, T.; Wang, W. Magnetic $\mathrm{Fe}_{3} \mathrm{O}_{4} @ \mathrm{CuO}$ nanocomposite assembled on graphene oxide sheets for the enhanced removal of arsenic(III/V) from Water. Appl. Surf. Sci. 2019, 466, 746-756. [CrossRef]

65. Raven, K.P.; Jain, A.; Loeppert, R.H. Arsenite and Arsenate Adsorption on Ferrihydrite: Kinetics, Equilibrium, and Adsorption Envelopes. Environ. Sci. Technol. 1998, 32, 344-349. [CrossRef]

66. Ren, Y.; Wei, X.; Zhang, M. Adsorption character for removal Cu (II) by magnetic Cu (II) ion imprinted composite adsorbent. J. Hazard. Mater. 2008, 158, 14-22. [CrossRef] [PubMed]

67. Matusik, J.; Hyla, J.; Maziarz, P.; Rybka, K.; Leiviskä, T. Performance of Halloysite-Mg/Al LDH Materials for Aqueous As(V) and Cr(VI) Removal. Materials 2019, 12, 3569. [CrossRef]

68. Zhu, Z.Z.; Zhang, j.; Zhu, Y.N.; Liu, J.; Tang, S.; Zhang, L.H.; Wang, Y.R. Dissolution, Stability and Solubility of Tooeleite[ $\mathrm{Fe}_{6}\left(\mathrm{AsO}_{3}\right)_{4}\left(\mathrm{SO}_{4}\right)(\mathrm{OH})_{4} \cdot 4 \mathrm{H}_{2} \mathrm{O}$ ] at $25-45^{\circ} \mathrm{C}$ and $\mathrm{pH}$ 2-12. Materials 2020, 10, 921. [CrossRef]

Publisher's Note: MDPI stays neutral with regard to jurisdictional claims in published maps and institutional affiliations.

(C) 2020 by the authors. Licensee MDPI, Basel, Switzerland. This article is an open access article distributed under the terms and conditions of the Creative Commons Attribution (CC BY) license (http://creativecommons.org/licenses/by/4.0/). 